\title{
Capitalism and Society
}

$\begin{array}{lll}\text { Volume 5, Issue } 3 & 2010 & \text { Article } 1\end{array}$

\section{Promoting Innovation: The Law of Publicly Traded Corporations}

Merritt B. Fox, Columbia Law School 


\title{
Promoting Innovation: The Law of Publicly Traded Corporations
}

\author{
Merritt B. Fox
}

\begin{abstract}
Improving economic welfare requires that society's scarce savings be allocated among proposed real investment projects in a way that appreciates the prospects of promising new innovations. Corporate and securities law help structure important elements of this process of allocation. This article sketches out an approach based upon a seemingly paradoxical analogy of a market economy's overall finance process to the way a hierarchical organization gathers and processes relevant bits of information dispersed among many individuals in order to make decisions. It thereby takes advantage of important thinking in communications and organizational theory about how to make organizations sensitive to the potentialities of new information and ideas.

The analysis suggests that established firms should pay out a relatively high portion of their cash flows. There should be a substantial venture capital sector and an active market for IPOs. Primary and secondary market prices should be relatively accurate. Incumbent managers of established firms should be judged in part by the medium term share price performance of their firms and poor performers should be under threat of replacement.

A comparison of four moments in economic history - the United States in the 1970s and 1980s, Japan since 1995, continental Europe since the 1995, and the United States since the 1995-supports these conclusions. The United States since 1995, relative to the other three moments in economic history, has had the least capital deepening and the fastest rate of growth in productivity per hour worked. It has also had, relative to the other three moments, a finance system most closely resembling what is called for here.

Achieving such a system requires rigorous, effectively enforced securities disclosure and anti-fraud laws. Corporate law must leave poorly performing incumbent management vulnerable to removal by hostile tender offer, or shareholder or independent board vote. Share price based compensation must be legally practical. And there must be serious constraints on non-pro-rata distribution among shareholders of the wealth created by the firm.
\end{abstract}

Author Notes: The author expresses thanks for the able research assistance of Jason Rogers, Vijay Singh, Barbara Gabor and Guyer McCraken. He also expresses appreciation for the helpful comments of Robert Cooter, Hans Schenk, Luca Enriques and participants at the Dalhousie University Law School Faculty Workshop, the RIETI Symposium on Financing Mechanisms to Promote Innovation (2006), the Conference on Entrepreneurship, Growth and Inclusion at the 
University of Buenos Aires (2009), and the Business Law and Innovation Program Conferences at Columbia Law School (2008), the Duisenberg School of Finance in Amsterdam (2009), and RIETI and Hitotsubashi University in Tokyo (2009). 
Fox: Promoting Innovation: The Law of Publicly Traded Corporations

Innovation is critical to improving a society's economic welfare. In the highly developed economies of North America, Western Europe and Japan, increases in the stock of physical capital and the exploitation of natural resources are no longer the primary sources of annual gains in per capita GDP. In the 43 year period from 1949 to 1992 , for example, only a quarter of the tripling in manufacturing output per hour worked in the United States was attributable to capital deepening. ${ }^{1}$ The rest of these gains came from other sources, the most important appearing to be improved products and processes. ${ }^{2}$

Law, and public policy more generally, can help promote innovation in a variety of ways. The appropriate level of protection for intellectual property and the funding of education and basic research are examples of ways that have received considerable attention. The focus of this article, however, is the impact on innovation of the securities and corporate law relating to publicly traded corporations. While economic analysis has dominated U.S. corporate and securities scholarship in recent decades, static efficiency has been the primary concern. The promotion of welfare enhancing innovation-dynamic efficiencyhas attracted little study.

This dearth of research is not surprising. At first glance, corporate and securities laws applicable to public corporations appear to have little to do with innovation. Further examination, though, suggests that they play a much larger role. In a capitalist economy, the decisions that determine which proposed real investment projects are, and are not, implemented are made within firms and in the larger financial markets in which these firms operate. ${ }^{3}$ Corporate and

${ }^{1}$ Calculations based on figures in William Gullickson, Measurement of Productivity Growth in US Manufacturing, MONTHLY LABOR REVIEW 23 (July 1995)

${ }^{2}$ For early work showing that capital accumulation does not explain most of the huge growth that occurred in output per capita in the $20^{\text {th }}$ century, see Robert M. Solow, Technical Change and the Aggregate Production Function, 39 REv. ECON. \& STAT. 312, 316 (1957) (from 1909-1949 in the United States, the increase in capital accounts for only about $1 / 8$ of the total increase in output per man hour over the period, suggesting, arguably, that technical change was arguably responsible for the remaining 7/8ths); Edward F. Denison, Why Growth Rates DifFer 318 (1967) (from 1950-1962, advances in knowledge was the most important source of economic growth for the United States and at least five of the eight western European countries surveyed). Easterly and Levine's more recent survey article of the larger growth accounting literature concludes that something other than physical or human capital accumulation explains the bulk of cross country differences in the growth of per capita income and that "technology is a formidable force" in determining this residual determinant of growth. William Easterly \& Ross Levine, It's Not Factor Accumulation: Stylized Facts and Growth Models, 15 THE World BANK ECON. Rev. 177, 192, 211 (2001).

${ }^{3}$ The importance of outside finance for project choice in an economy has been recognized for a long time, and has continued to be a focus of research. See, e.g. JOSHPH A. SCHUMPTER, THEORY of ECONOMic DeVelopment (1911); JohH R. Hicks, A THEORY of ECONOMiC History 143-145 (1969) (emphasizing the liquidity provided by financial markets as critical to early industrial development in England, France and Holland); Raghuram G. Rajan \& Luigi Zingales, Financial 
securities laws help shape the ways these decisions are made. From a social point of view, the ultimate goal for these systems of corporate governance and finance should be that they work in such a way that scarce savings are matched with the most promising investment project proposals in the economy. To the extent cost effective, every knowable bit of information that is relevant to predicting the future cash flows associated with each proposed investment project in the economy should be gathered and analyzed. The projects should then be ranked in terms of their risk adjusted expected returns. The ones chosen to be implemented should be selected in rank order of these returns, going down the list until the available savings in the economy are exhausted. ${ }^{4}$

Making the best choices and promoting innovation are closely related. Unless an investment project proposal is innovation-based, it is unlikely to be highly promising. Non-innovation-based project proposals-ones in wellestablished products or services produced by a well-established technology-are unlikely to have above normal expected returns because they have been obvious for some time. Any potential above normal returns have usually been competed away already by other firms making similar investments. Such investments cannot contribute significantly to growth beyond providing a little more capital deepening in an already capital rich economy. In contrast, projects with unusually high returns are very likely to be innovation-based. These are the ones that can contribute to growth. In the standard language of financial economics, these are

Dependence and Growth, 88 AM. ECON. REV.. 559 (1998) (cross country study showing relationship between financial market development and rate of growth of firms relying on external finance and relationship of such development and flourishing of smaller high technology firms); Ross Levine, Finance and Growth: Theory and Evidence, in HANDBOOK OF ECONOMIC GROWTH (2005). For a skeptical view, see JOAN RoBINSON, THE RATE OF INTEREST AND OTHER ESSAYS (1952) (finance follows industry).

${ }^{4}$ To illustrate, suppose that an economy has in total $\$ 30$ million to allocate and there are five proposed projects, each of which will cost $\$ 10$ million. Each will pay back for certain the amount listed below in one year and nothing thereafter.

$\$ 30$ million to Allocate

Five Proposed Projects Costing \$10 Million Each

$\begin{array}{lc}\text { Project } & \text { Payback for certain in One Year } \\ \text { A } & \$ 15 \text { million } \\ \text { B } & \$ 14 \text { million } \\ \text { C } & \$ 13 \text { million } \\ \text { D } & \$ 12 \text { million } \\ \text { E } & \$ 11 \text { million }\end{array}$

Choices must be made because only three of the five projects can be funded. Economic welfare is maximized if Projects A, B and C were the ones to be implemented. It would be poorly served if instead, for example, Project E was implemented and Project A was not. 
Fox: Promoting Innovation: The Law of Publicly Traded Corporations

the positive net present value (NPV) projects, and firms that can find and implement them are the economy's "growth" firms.

Answering the question of how law, through its influence on the behavior of a variety of actors - investment project proponents, persons working in established firms and in financial intermediaries, and individual investors - can make the overall system more sensitive to the potential of promising innovationbased investment project proposals is a very large project. This Article represents a preliminary first step in this project, in essence a sketch of how to think about the problem.

Part I of this article lays out the basic institutional realities: who are the likely proponents of promising innovation-based project proposals and who decides whether ther proposals are implemented or not.

Parts II, III and IV address the question of how real investment decisions are made in the economy. Developments over the last few decades in the fields of the economics of contracts and organization and corporate finance have enhanced our understanding of many of the parts of the system making these decisions. The discussion here builds on this progress, but steps back and takes a very abstract look at the system as a whole, viewing it as a large organization that utilizes disparate bits of information held by many different participants to make its decisions. This organization, while far more complex than a single hierarchical organization, shares some important features with its simpler counterpart. The organizational analogy highlights important differences between a market-based system for making real investment decisions that have uncertain outcomes and one for allocating scarce resources purely for current production and consumption. Communications theory sheds much light on the behavior of hierarchical organizations. The analysis in these parts of the paper uses communications theory instead to analyze the organization that makes real investment decisions in a market economy and to suggest the features of the finance process - the system in an economy that links savings to real investment that would make it relatively more or less sensitive to the potentialities of innovative proposals.

Part V applies these lessons to institutional realities addressed in Part I. It suggests certain characteristics that in combination would make an economy's finance process more sensitive to innovative ideas: an active market for corporate control, relatively high payouts of the cash flows of established corporations to their investors, a substantial venture capital sector, an active market for IPOs, a high level of corporate transparency, and relatively accurate primary and secondary share prices.

Part VI presents some crude empiricism. It uses the story from Part V to help explain four moments in economic history: the United States in the 1970s 
and 1980s, Japan since the mid 1990s, continental Europe since the mid 1990s, and the United States since the mid 1990s.

Finally, Part VII looks at the role of securities and of corporate law in promoting these innovation sensitive characteristics of the finance process.

\section{The InSTITUTIONAL REALITY}

The employees of large, established corporations are a rich source of innovative project proposals because the physical and organizational assets of these corporations facilitate the discoveries that give rise to ideas for new products and processes. ${ }^{5}$ These employee proponents of innovative projects are likely to go first to top management to try to persuade them to implement the proposal. ${ }^{6}$ Many highly promising proposals made by a corporation's employees are accepted. Both theory and experience tell us that the top managers of established corporations also often reject many such proposals. Such a rejection often represents a failure of the firm's internal capital market. ${ }^{7}$

As a consequence, we witness, particularly in the United States, the spinoff phenomenon: an employee or a group of employees of an established corporation leave to establish a new business based on an idea developed while in their previous employment. Many of the most important innovation-based firms in the U.S. economy have grown out of these spin-offs. ${ }^{8}$ If these spin-offs had not occurred, the promising project proposals that formed the bases of these firms would have gone to waste. Scarce savings would instead have gone to less promising projects and there would have been less economic growth.

It is in society's interest, to the extent cost effective, to minimize the number of promising innovative project proposals developed by employees of established corporations that go to waste. Such waste will occur if the proposal is neither implemented by the established corporation employing the proponent nor becomes the basis of a spin-off that receives funding from some other source. The goal of minimizing the waste of promising innovative project proposals poses a

\footnotetext{
${ }^{5}$ Thomas Hellmann \& Enrico Perotti, The Circulation of Ideas in Firms and Markets (2006) Available at http://www.lse.ac.uk/collections/RICAFE/pdf/RICAFE2-WP30-Hellmann.pdf.

${ }^{6}$ Mariagiovanna Baccara \& Ronny Razin, Governance and Innovation; WILLIAM J. BAUMOL, ROBERT LiTAN \& CARL J. SCHRAMM, GOOD CAPITALISM, BAD CAPITALISM 82 (2007).

${ }^{7}$ Gilson and Bankman suggest an alternative explanation for some spin-offs. They suggest that often the high-powered incentives offered a proponent in the context of a venture-capital-financed spinoff are more attractive than what the established firm offers because such high powered incentives undermine the team effort for successful R\&D. Ronald Gilson \& Joseph Bankman, Why Start-ups?, 55 STAN. L. REV. 289 (1999).

${ }^{8}$ See, e.g., Amar Bhide, How Entrepreneurs Craft Strategies that Work, 72 HARV. Bus. REV. 150, 151 (1994) (discussing how a large percentage of the founders of the fastest growing companies "replicated or modified an idea encountered through previous employment").
} 
Fox: Promoting Innovation: The Law of Publicly Traded Corporations

critical challenge for an economy's system of finance. One component of this challenge is to shape the environment in which established corporations operate so that they have decision processes that decision makers pass up as few promising innovative project proposals as possible. Ultimately, however, there are limits to how much large established corporations can be improved in their capacity to identify and act on innovative proposals. Thus a second component is the facilitation of an effective spin-off phenomenon so that proponents of project proposals rejected by established corporations have other possible sources of funding - sources with the capacity to recognize which proposals are promising. The existence of these other sources of funding also facilitates implementation of the many promising innovative project proposals that originate from universitybased and independent proponents.

\section{STEPPING BACK}

How can we best describe conceptually the financial system of a modern capitalist economy? Despite being market-based, the system shares important characteristics in common with a hierarchical organization. This proposition may seem surprising because we tend to think of markets and hierarchical organizations as sharply distinct substitutes for each other. Where the question is how to allocate scarce resources efficiently for current production and consumption, a market and a hierarchical organization do in fact use distinctly different mechanisms for dealing with widely dispersed information. But where the allocation problem includes choices among proposed investment projects with uncertain future returns, the mechanisms used by the two systems involve greater overlap. This overlap allows us to make use of thinking regarding what makes organizations more innovative, and in so doing provides guidance concerning ways to structure the finance process to promote innovation.

\section{A. Contrasting Market and Hierarchal Allocation Systems for Current Production and Consumption}

The sharp contrast between market and hierarchical allocation systems with regard to current production and consumption can be considered in the context of a highly simplified World A. In World A, there exist no investment opportunities and all of the economy's fixed quantities of its two factors of production available in given period - labor and land - are devoted to the production of two outputsapples and nuts - for consumption entirely during that period. The market will decide the total production of each output, the amount of labor and land that will be devoted to each, the method of production for each, and the allocation of each output among the individuals in society. These decisions will be determined by 
the initial distribution of labor and land among individuals, the utility function of each individual, and the production function for each output. Other than the input and output prices and the reasonably self-evident qualities of each product that consumers easily learn from life experience, no participant in this decision process needs any information from anyone else. The individual looks only at his utility function and how much labor and land he owns. The producer looks only at the production function. World $\mathrm{A}$ is the quintessential example of the virtues of the market economy in eliminating the need for communication among participants. And if the appropriate conditions are met, the market's solution will be Pareto optimal. ${ }^{9}$

Alternatively, these decisions - what combinations of land and labor to use to manufacture apples and what combination to manufacture nuts; how many apples and how many nuts to produce; how many of each should go to each consumer - could be decided by a large hierarchical organization through central planning. In order to come up with a Pareto efficient solution, information would need to be gathered about the amount of land and labor available, the range of technologies available for producing each output, and the tastes of each consumer in terms of the rate at which they would trade off nuts for apples for each given possible allocation of nuts and apples that the consumer might receive. This would be far too much information for one person to gather and process, and so the information would need to be gathered by many individuals at the front line, processed and summarized up through a number of layers of intermediate level officials and finally presented to a top person or body in the form of a discrete number of proposed choices with summarized descriptions of the consequences of each.

Avoiding central planning's huge cost of information handling, and its inevitable errors from information failures, has long been heralded as the market's great advantage. ${ }^{10}$ The story is familiar. Without any of the communication involved in the hierarchical organization solution, an initial set of prices would develop. People would see advantages in deciding to purchase various amounts of labor and land in order to produce various amounts of apples and nuts in particular ways. Individual consumers would decide how much of each to purchase from what was produced. These initial decisions will affect the prevailing prices for land and labor and for apples and nuts that in turn would lead to changes in these decisions and so on until prices reach an equilibrium,

\footnotetext{
${ }^{9}$ World A is the world described in Francis Bator's famous article showing the conditions under which a market economy can solve economics' basic "how", "what" and "for whom" questions in a pareto optimal way. Francis M. Bator, The Simple Analytics of Welfare Maximization, 47 AM. ECON. REV. 22 (1957).

${ }^{10}$ Freidrich Hayek, The Use of Knowledge in Society, 35 Am. ECON. Rev. 519 (1945).
} 
Fox: Promoting Innovation: The Law of Publicly Traded Corporations

reflecting, under appropriate conditions, a Pareto efficient solution to the economy's "how," "what" and "for whom" questions.

\section{B. Using Market Allocation Systems for Real Investments}

The market allocation system with regard to real investment is fundamentally different. To see this, consider the highly simplified World B, where there are only investment opportunities, no current consumption. A single productive resource, land, must be allocated between two different kinds of real investment opportunities, $\mathrm{X}$ and $\mathrm{Y}$, which, in different ways with not yet fully understood results, will produce a single output, nuts. Consider how a market would solve this problem. As in World A, the endowment of land is arbitrarily allocated among investors. Project choice in the economy, i.e., how much in aggregate is invested in each of $\mathrm{X}$ and $\mathrm{Y}$, is determined by these investors. By assuming that each unit of land invested in $\mathrm{X}$ or $\mathrm{Y}$ represents a separate project, we can abstract away the problem of collecting savings from more than one individual for a single project. The projects require no management. The supply of each of the two types of real investment opportunities is, as in the real world, infinitely elastic. The sole result of an investor investing in an $\mathrm{X}$ or $\mathrm{Y}$ project is his receiving a return in nuts in period $t+1$, which the investor will then consume. The returns on each kind of project are uncertain in period $t$. In $t+1$, all $X$ projects will turn out to have an identical return and all $\mathrm{Y}$ projects will also have an identical return. The return on the $\mathrm{X}$ projects will probably be different from the return on the $\mathrm{Y}$ projects, however. Information useful for predicting the returns from each of the projects is dispersed among many individuals, each of whom knows some bits of information that not all other individuals know.

\section{Contrasting Allocation for Current Production and Consumption with Allocation for Real Investment}

Using, in each case, a market system of allocation, one can contrast what is required for an individual to maximize her utility in World A and World B. In World A, beyond knowing the market prices of the inputs and the outputs, all the consumer needs to do is to look inside herself at her utility function. In World B, her views of the characteristics of any given possible portfolio require her to look outside and are based on information that she collects concerning the potential returns of $\mathrm{X}$ and $\mathrm{Y}$ in $\mathrm{t}+1$. The expected return and risk characteristics of $\mathrm{X}$ and $\mathrm{Y}$ are not known to her through experience the way the characteristics of apples and nuts are. Thus, the economy's aggregate decisions concerning the amount of resources invested in $\mathrm{X}$ and $\mathrm{Y}$ is determined by the information each investor possesses. 
A comparison of Worlds A and B illustrates a tremendously important point. In a world where there is real investment, each individual, in order to decide where her available resources should be invested, must look outside of herself to acquire information. Real investment opportunities are not scarce commodities that are in the first instance competitively priced. The cost of implementing an investment opportunity is the cost of the needed real resources. The prices of these real resources are ordinarily not closely related to the opportunity's prospects.

This need to look outside for information not contained in prices can help explain many institutions existing in the real world. Consider World B', which includes investment advisers and financial intermediaries. It is reasonable to assume that, absent the need to decide the placement of her savings, the average investor would not in the ordinary course acquire very much information about the prospects of $\mathrm{X}$ and $\mathrm{Y}$. And, for the standard reasons, described briefly below, it is also reasonable to assume that the market in which she can acquire such information on a piece by piece basis falls far short of perfection. To solve the problem of her ignorance, the investor, in essence, "hires" persons more knowledgeable than she is. This more knowledgeable person may be an investment adviser hired to give advice, or he may be the agent of a financial intermediary in which the investor invests, who in essence makes decisions on the investor's behalf.

The intermediary in which the individual invests might itself himself not possess much information about the prospects of $\mathrm{X}$ or $\mathrm{Y}$, but might know more than the individual investor concerning who would have such information. And so the process of delegation might repeat itself one or more times. Thus, the investor might invest in a financial intermediary (for example, a venture capital firm or mutual fund), the intermediary in a corporation, and the corporation would then invest the funds it receives in an $\mathrm{X}$ or $\mathrm{Y}$ project. The special knowledge of the investment company might be in selecting the corporation with the most expertise in choosing among real investment projects. ${ }^{11}$ In addition, the investor, the financial intermediary and the corporation might each seek outside advice as well to make their decisions.

The position of the investor in relation to the network of persons she directly or indirectly "hires" is analogous to the head of a hierarchical

\footnotetext{
${ }^{11}$ Corporations are normally seen to exist for two reasons. First, the amount of capital needed for the minimum efficient scale of many projects is too large for a single individual to provide, and the corporation is a legal form that enables the proponent of such a project to gather this necessary amount from many different individuals. Second, once the investment has been made, the project must be managed for it to produce a return. World B' presents neither of these problems. It illustrates that corporations have yet a third function, as expert intermediaries in the process of project choice.
} 
Fox: Promoting Innovation: The Law of Publicly Traded Corporations

organization. How much of the investor's savings is ultimately invested in $\mathrm{X}$ and how much in $\mathrm{Y}$ is equivalent to a decision of this organization. Because the head of a large hierarchical organization cannot accumulate and analyze all the information necessary for her to make sensibly all of the organization's decisions, much of her work consists of delegating to others who have accumulated more information in particular areas and the authority to make decisions on the organization's behalf. The average investor is in the same position when faced with real investment decisions. Each member of the investor's network, like each subordinate member of an organization, is a decision maker in the sense that his actions to some extent influence the outcome of the whole process. But the investor, like the head of an organization being ultimately responsible for its decisions, is ultimately responsible for the decision as to which real investments her savings go to because her choices dictate the structure of the rest of the process. Thus relying on the market to allocate resources for investment, unlike relying on it to allocate resources for current production and consumption, involves mechanisms which in some important respects have an organizational character.

\section{Introducing Ongoing Firms and Reinvestment}

Worlds B and $\mathrm{B}^{\prime}$ not only abstract out production decisions - decisions as to how existing productive capacity is to be used - but they abstract out firm reinvestment as well. In the real world, firms also often reinvest the returns generated by existing projects in new projects rather than paying out these returns to investors. The role of the finance process also includes control reassignment, the choice of who over time makes these decisions of whether and where to reinvest. $^{12}$

\footnotetext{
${ }^{12}$ In the real world, control reassignment also comes into play as an antidote to management not making optimal production decisions in the use of the firm's existing facilities. This paper abstracts out production decisions for two reasons. First, the focus of the paper is on project choice and its influence on the level of innovation in an economy. Second, as will be discussed in Part III.E infra, most agency costs of management arise in connection with their project choice decisions, not their production decisions. Nevertheless, a more fine-grained analysis will require some attention to control reassignment because of managerial production decision deficiencies. As will be discussed in Part III.C infra, innovative project proposals are normally a package of an investment idea and a plan for the proposal's proponent to manage the project. Such proponents usually do not have proven production decision skills. Ongoing monitoring of the production decisions of the proponent and control reassignment where the proponent falls short is thus an important function of the funding source for this kind of project, whether the funding source decision makers are the principals of a venture capital firm or the top managers of an established corporation. The funding source is unlikely to provide the financing without the right to perform this function.
} 
To incorporate the reinvestment decision aspect of reality, consider World C. World C is like World B with the following modifications. In World C, there is still no consumption until period $\mathrm{t}+1$, but there are two earlier periods, $\mathrm{t}$ and $\mathrm{t}-1$. There is investment of the single productive input, land, in both these earlier periods. In period $\mathrm{t}-1$, each individual investor starts with an arbitrarily assigned amount of land. All the land in the economy must be allocated between two different kinds of real investment opportunities, $\mathrm{U}$ and $\mathrm{V}$, which will produce a single output, also land, through a transformation over time in different, not yet fully understood, ways. Again each unit of land invested in U or V project represents a separate project and the supply of each of the two types of real investment opportunities is infinitely elastic. The sole result of an investment in a $\mathrm{U}$ or $\mathrm{V}$ project is a return in land in period $\mathrm{t}$. All $\mathrm{U}$ projects will turn out to have an identical return in $t$ and all $\mathrm{V}$ projects will also have an identical return in $\mathrm{t}$ that is probably different than that of the $\mathrm{U}$ projects. In period $\mathrm{t}-1$, these returns will be uncertain.

In $\mathrm{t}-1$, individual investors do not invest directly in projects; they invest in firms. An investment in a firm consists of one unit of land and each firm decides whether to invest the unit of land it receives from its shareholder in a $U$ or a $\mathrm{V}$ project. To the individual investors, all the firms appear the same in $\mathrm{t}-1$, but in fact they are not. Each firm has its own special skills at making investment project choices, which involve gathering information and making a decision. Some firms will be more skilled than others. Investments in period $\mathrm{t}-1$ yield their return in period t, which, absent shareholder intervention, will then be reinvested by management, who will use their skills to make a fresh choice in either an $\mathrm{X}$ or a $\mathrm{Y}$ project that will pay its returns in nuts in $\mathrm{t}+1$.

The share obtained by the individual investor in a firm in $\mathrm{t}-1$ includes the right in $t$ to change management of the company to one that would pay out the returns instead of exercising its choice skills again and reinvesting. To aid in deciding whether to exercise this right, investors in period $t$ are able to obtain some information concerning the choice skills of each firm. This information would consist of the return on the project choice made by the firm in period $t-1$ (which, by itself, is a signal concerning the skills of the firm, but a noisy one), the firm's announced rationale for the choice made in $\mathrm{t}-1$, and information about the world that would permit an evaluation of the soundness of the announced rationale.

In period $t$, each investor must initially decide whether to change the management of any of the firms in which she invested in period $t-1$, in which case she would receive the return in the form of land on the investment made by the firm in $\mathrm{t}-1$ in a $\mathrm{U}$ or $\mathrm{V}$ project. She then must decide what to do with any units of land so received. She has three choices: (1) invest directly in X or Y projects, which will return nuts for consumption in period $t+1$, (2) with the 
Fox: Promoting Innovation: The Law of Publicly Traded Corporations

intention not to exercise the option to change management, purchase from other investors shares of firms that invested in $U$ or $V$ projects in $t-1$, in which case she will receive a return in the form of nuts for consumption in $t+1$ arising from the investment the purchased firm makes in period $t$ in an $\mathrm{X}$ or $\mathrm{Y}$ project, or (3) with the intention to exercise the option to change management, purchase from other investors shares of firms that invested in $U$ or $V$ projects in $t-1$, in which case she will receive a return in $t$ in the form of land. If she makes the third choice, she faces the same three choices with the land so received. The same is true of sellers in period $t$ of shares of firms that invested in the $U$ or $V$ projects in period $\mathrm{t}-1$.

Now consider World C', a refinement of World C. As with B', the model is modified to permit the investor to invest in intermediaries in period t. Assume that each unit of land invested in an intermediary creates a separate entity. ${ }^{13}$ As in World B', assume that the typical investor in period $t$ does not possess much information about the prospect of the $\mathrm{X}$ and $\mathrm{Y}$ projects. Nor does she possess much information about the project choice skills of the firms that in $t-1$ invested in the $\mathrm{U}$ and $\mathrm{V}$ projects. A financial intermediary can again perform the function of being a more knowledgeable person to whom to delegate the range of decisions that the investor would otherwise have to make. At each level of decision, working from the individual investor through to the person making the actual decision to fund a real investment or to change control, the decision-maker through some combination of gathering information for himself, seeking advice and delegation - deals with the problem that others have much relevant knowledge that he lacks. An analogy to a hierarchical organization can again be made. Each new project funded and each control reassignment occurring in period $t$ is the result of a structure of decision that can be traced back to an investor, but others play important roles within the structure.

\section{E. Outline of a Theory and Its Application}

In a world with real investment projects yielding uncertain returns and an uneven initial distribution of information, the use of competitive markets to make the economy's decisions does not, as it does in World A, eliminate the need for each individual investor to collect pieces of information from, seek the advice of, or delegate decisions to, other persons who possess bits of information that the individual investor does not have. The analysis that follows takes seriously the

\footnotetext{
${ }^{13}$ This unrealistic assumption is made to simplify the exposition of the particular points developed in this model. It ignores the fact that economies of scale are a vital reason why an investor chooses to delegate decisions to an intermediary rather than gather and process information about real investment opportunities themselves.
} 
analogy of the market-based system of making project choice and control reassignment decisions to a hierarchical organization suggested by World C'. This seemingly incongruous analogy is, of course, highly imperfect. To start, the analogy ignores the existence of economies of scale both in the production of goods and in the information gathering and processing undertaken by corporate officials and financial intermediaries with regard to real or financial investment opportunities. These economies of scale drive both firms and financial intermediaries to seek funds from multiple sources. ${ }^{14}$ The analogy also sidesteps the role played by prices in secondary securities markets and the capacity of the mechanisms of market efficiency to push these prices toward reflecting the views of the best informed investors. And it ignores the ability of a person who is more sure of his views than others to magnify his influence in project choice by dividing up the income stream produced by a proposed project and offering to invest a given amount of her savings in the project in return for the right to receive the riskiest portion of the stream, with others investing in the project in return for the right to receive the less risky portions. Notwithstanding these limitations, the analogy, it will be seen, guides the inquiry into the relationship between finance and innovation in a useful fashion.

The theory here will be developed in two steps. The first step, developed in Part III, is a micro analysis: a study of the structure which determines how any particular project choice or control reassignment decision at the real level is made. The second step is a macro analysis: a study of how the finance process functions as a system and its impact on innovation.

The micro-analysis is informed by the enormous progress, on both the theoretical and empirical fronts, that has been made over the last few decades in the economics of contracts and organization and in corporate finance. It starts at the level of a proponent seeking project funding. The messages which such a proponent emits to possible funding sources are examined. Next, top managements of established corporations are analyzed. A series of questions are raised and dealt with. How does corporate management process information emitted by investment project proponents? What other information does corporate management look at to make these decisions? What values do corporate managers seek to satisfy, and how are the decisions they make related to these values? How are these decisions influenced by how the decisions will appear to financial intermediaries, investor advisory services, and investors themselves? Finally, what kinds of information does top corporate management emit to such other

\footnotetext{
${ }^{14}$ These scale requirements for modern industry compound the need for delegation of decisionmaking because, even if each investor were as informed and capable as the delegate, the coordination among a large number of investors necessary to make group decisions is impractical for most questions.
} 
Fox: Promoting Innovation: The Law of Publicly Traded Corporations

entities and persons? The same kind of analysis, one step up the ladder, is then made with respect to the principals of financial intermediaries.

The macro analysis starts with the proposition that every economy, whether centralized, pure market, or otherwise, needs a process which takes account of information held by disparate sources in order to decide which real investment projects shall receive society's scarce savings. In a centralized economy, this would be a simple hierarchical organization. In a market economy, the process also has some features that resemble a simple hierarchical organization, but given the millions of individual investors, is much more complex. Our goal for this process is to enhance the capacity of the economy's finance process to identify and implement the most promising investment projects, to the extent that doing so is cost effective and consistent with maintaining production and output choice efficiency. The most promising projects are typically innovative ones. Part VI will make some judgments concerning what characteristics an economy's finance process should have in order to best serve this goal. These judgments will be made by seeing how the elements studied in the micro analysis aggregate and by referring to a rich body of social science literature concerning organizations as communications phenomena. These judgments will be tested in Part VII by some crude empiricism, using stylized facts about the U.S. economy in the 1970s and 1980s versus the last fifteen years and versus the economies in Japan and continental western Europe in the last fifteen years. In Part VIII, these judgments will be applied to identify the features of the corporate and securities law of publicly traded firms that would best promote innovation.

\section{Micro Analysis}

The micro analysis discussion begins with an examination of two basic concepts: the special characteristics of information as a commodity and general principles as to how individuals and organizations process incoming information. This is followed by a brief sketch of each level of decision-making that plays a potential role in determining whether an investment project proposal is implemented - the individual proponent of the project, the established corporation that makes funding decisions relating to proposals by its employees, and various types of financial intermediaries - in terms of the incentives of the actor, the way the actor will process incoming information and the communications the actor will emit.

\section{A. Information as a Special Commodity}

As is well known, information is not a commodity that is typically bought and sold on a piece-by-piece basis in the ordinary fashion. The extreme imperfections 
in the market for information are key reasons for the development of firms and financial intermediaries, and of financial information services that provide investors, financial intermediaries and firms with advice as to the best financial or real investments. They also help explain why these activities are not significantly threatened by the potential competition of investors purchasing raw information for themselves to use in making direct investments in real investment opportunities.

\section{Economies of scale}

One source of information's uniqueness as a commodity is that, above and beyond what must be paid the seller of a piece of information, information is costly to find and to utilize. Intermediaries and information services save the investor time by gathering and processing the information for him. There are enormous economies of scale in gathering and processing the same information for multiple individuals. An intermediary can make an investment decision for, and an information service can give advice to, thousands of investors with millions of dollars in resources using little more effort gathering and processing information than one investor acting on his own would have to exert if he wanted to make a decision of the same quality. ${ }^{15}$

\section{Economies of scope}

The other source of information's uniqueness relates to the existence of economies of scope in terms of gathering different bits of information. A firm, financial intermediary or investment information provider is likely to be serving aggregate investment resources of considerable size, usually ultimately traceable to many different individual investors. As a result, for the economies of scale reasons discussed just above, the aggregate gain to such a person or entity from finding better investment opportunities justifies, on a cost benefit basis, gathering and analyzing far more different bits of information than the typical individual would likely gather because of the much smaller gain he could acquire from using it. Economies of scope arise from gathering so many more bits of different information because, with this higher volume, the firm, financial intermediary or

\footnotetext{
${ }^{15}$ In terms of speculative profits from trading already outstanding securities, these economies are counterbalanced by the fact that the more broadly dispersed the information, the greater the effect on the demand and hence on the price of the security involved, and the less profit that can be obtained by trading on the information. This tradeoff is much less severe in the case of the finance process steering funds to the real investment projects with the best prospects. Of course an investor's returns on an investment in a real project are affected by the economy's aggregate amount investment in this and any other projects based on the same idea.
} 
Fox: Promoting Innovation: The Law of Publicly Traded Corporations

information service can cost effectively have an employment or other relational contract arrangement with its information sources. Such an arrangement greatly facilitates the acquisition of information, but it is only practical if there is a regular transmission over time of large amounts of information.

There are three reasons why an employment or other relational contract arrangement is often the superior forum for transfer of information. First, as Coase famously pointed out, there is a cost in using the price mechanism which makes it, under some circumstances, uneconomical in comparison with other forms of allocation. ${ }^{16}$ Relative to the usually low value of the typical individual bit of information, this cost can be large. The generation and transfer of information by command within an organization will avoid this cost and thus will often be more economical than use of the market to acquire information. ${ }^{17}$

Second, compared to an individual investor, a firm, financial intermediary or investment information provider is frequently able to provide much more incentive to an information source to produce and provide information. This again relates to the public goods aspect of information: once a piece of information has been produced (discovered), the cost of transmission to other people is very low. Because of the intangible nature of the commodity, once the producer has revealed the piece of information to one person, it is difficult, unless the information is subject to some kind easily enforceable intellectual property protection, for the producer to have it excluded from use by others. The dilemma faced by the private producer is that he wants to maximize his rents and have the information used only as widely as the producer of any valuable input would want it used (i.e., to the point where $\mathrm{MR}=\mathrm{MC}$ ). The revelation of the information to another undermines his monopoly position, since anyone who receives it can then "produce" additional units of it at very low marginal cost. If an information source and a firm, financial intermediary or investment information provider are in an employment or other relational contract arrangementwith each other, they can agree that the information will not be revealed to others. They can then share the larger rents that will result from limiting the scope of decisions based on the information or the spread of advice utilizing the information.

Third, there are barriers to the transfer of information through ordinary market transactions because it is hard for a user to evaluate information without

\footnotetext{
${ }^{16}$ Ronald Coase, The Nature of the Firm, 4 ECONOMICA 386 (N.S. 1937). See also John Commons, INDUSTRIAL ECONOMICS (1934). Problems with the price mechanism include: the costs of discovering what the relevant prices are, and the dilemma between the cost of negotiating and concluding a separate contract for each exchange transaction and the inflexibility of a nonrelational long-term contract to avoid these negotiating costs.

${ }^{17}$ Coase, supra note 16 , at 391.
} 
learning it, at which point there is no need to pay for it. ${ }^{18}$ Since suppliers of information are likely to demand payment or a promise to pay before revealing their information, there is an incentive for users to get their information only from suppliers who have established their trustworthiness over an extended, continuous relationship. The establishment by a source of such trustworthiness is a component of, in the language of the next section, the "authority" of the source in the eyes of the user. As information frequently becomes just one component of an investment decision, the supplier may not be sure himself of the value of the information because such an assessment requires specialized knowledge which the user alone has. In this situation, the trustworthiness of the supplier is not adequate evidence that the knowledge is worth using, and the user will still be reluctant in advance to pay or promise to pay for the information. In such a situation, there is a particularly strong incentive for an employment or relational contract arrangement allowing for an ex post settling up that accurately reflects the information's value, rather than an ordinary market link between them. ${ }^{19}$

\section{B. Rules Relating to Incoming Information: Authority and Interest}

Each participant in the finance process gathers and processes information, either messages from others or physical observations about the world, in order to determine what his best course of action will be. An individual or organization is physically capable of gathering an enormous number of bits of information at quite low cost. But processing this information - absorbing it and calculating how it should influence the recipient's choice of alternatives - is costly in terms of time. Thus, the recipient needs to assign priorities to incoming messages. The higher the priority, the more likely the message will be considered seriously and influence the recipient's behavior. Priority is assigned by rules: authority rules and interest rules.

\footnotetext{
${ }^{18}$ Kenneth Arrow discusses these second and third reasons considered in the text as to why an employment or relational contract arrangement may be the superior forum for information transfer in Economic Welfare and the Allocation of Resources for Invention, in THE RATE AND DIRECTION OF INVENTIVE ACTIVITY 616, Richard R. Nelson, ed. (1962). For discussions by Arrow that more explicitly consider the aspects of information that help define the borderline between decisions made by formal organizations and those made by the market, see Kenneth Arrow, THE LIMITS OF ORganization 33- 43 (1974); Kenneth Arrow, Vertical Integration and Communication, 6 BeLL J. ECON. 173 (1975).

${ }^{19}$ Oliver Williamson points out that in addition to the virtue of an employment relationship in building the authority of the information source through what he refers to as "experience ratings," it imbues the source and recipient with a sense of joint purpose which also facilitates transfer. Oliver Williamson, MARKETS AND HIERARCHIES 36 (1975).
} 
Fox: Promoting Innovation: The Law of Publicly Traded Corporations

\section{Authority rules}

Authority rules assign priority to incoming information on the basis of its source. They relate to the recipient's opinion of the competence and trustworthiness of the source. The recipient is essentially using the source as a substitute for gathering and processing the information himself. Competence is a concern because the source is rarely just a conduit. Rather, the messages the source emits are in part based on her interpretations of the information that she in turn has received. Trustworthiness is a concern because the source, in deciding what messages to emit, may have an interest in manipulating the recipient into acting in a fashion which is different from what, given the objective facts, is in the recipient's own best interests.

The degree of authority that a recipient assigns to a message from a particular source is determined by several factors. The first is incentive-based authority: does the source have any reason to transmit information in a way that would create a false or misleading impression? Second is the reputation of the source: what do other persons, who themselves have authority, say about the source in terms of competency and motivation? Finally, and most importantly, is experience-based authority: what has been the recipient's past experience with the source? Authority rules, like other rules of information processing, are subject to feedback, and over the long run the quality of the messages from any particular source will affect the authority that the source enjoys.

Information can range from being raw data to being highly conclusionary. The most conclusionary information is a naked recommendation to the recipient as to what course of action he should take. The more conclusionary the information, the more important authority is in determining its priority.

\section{Interest rules}

Interest rules refer to rules that assign priority because of the content of information: what it is about. A recipient is concerned with only certain kinds of messages: those that analysis or experience suggest would be useful in determining the course of action that will best correspond to his particular interests. A securities analyst who is an expert in the automobile industry is valued and compensated for sending out very specialized kinds of messages. His interest rules in terms of processing incoming information emitted by others would obviously be quite different from those of an analyst who is an expert in the cosmetics industry. Similarly, a mutual fund that has a declared policy of investing in blue chip stocks has very different interest rules from a venture capital firm specializing in high technology companies, but each would give relatively high priority to a much broader range of information than would the 
auto or cosmetics securities analysts. An individual investor would typically have a very broad range of interests - because she is interested in knowing which among the huge variety of investment opportunities available are the best places to put her savings. But she also would usually prefer to receive information in highly conclusionary form. Thus, information from sources which are not highly authoritative does not get much priority from individual investors.

\section{Information Flow: Proponents}

Every proposed investment project is assumed to have a proponent - a single individual seeking funding to implement the project that she intends to run. ${ }^{20}$ The proponent offers the combination of an idea and the willingness and desire to bring the idea into reality should the project acquire funding. The proponent may be an employee of an established firm appealing to her superiors. Alternatively, she may be a person who developed the idea at the established firm where she worked but is seeking external funding to implement it independent of this firm, or a university based or wholly independent person who is seeking external funding.

A proponent is likely to know more about the prospects of her project than anyone else, although others know information relevant to predicting the project's future that she does not know. She also has an interest in the project being funded. Thus what she knows is very important to everyone else in the chain of decision between her and the ultimate investors who would supply the funds, but, inherently, what she says is not totally trustworthy.

Proponents who are employees of an established firm seeking funding from top management need to rely primarily on experienced-based authority. Incentive-based authority is hard to establish within the kinds of compensation arrangements that appear workable in established firms. Proponents who appeal to outside sources of funding have less experience based-authority in the eyes of these sources. Incentive-based authority and reputation-based authority are thus more important.

In the case of highly innovative project proposals, the fact that a proponent seeking internal financing must rely relatively more on experience-based authority makes, at the margin, internal finance less attractive relative to external finance. This is because many of the best such ideas are gestalt phenomena which may come from people with little previous experience or accomplishment in the area of concern. Skepticism of some relevant, broadly held scientific belief is often a precondition for original thinking. Moreover, the typical proponent in

\footnotetext{
${ }^{20}$ The proponent could also be a small cohesive team of individuals, but for convenience, the proponent will be treated throughout this discussion as though it is a single individual.
} 
Fox: Promoting Innovation: The Law of Publicly Traded Corporations

industries characterized by rapid technical change is young and highly mobile, reducing the opportunities to develop experience-based authority in the eyes of the top managers of his current employer.

Internal finance is also relatively less attractive at the margin in the case of highly innovative proposals for reasons related to the information asymmetry between the proponent and the funding source. For both innovative proposals and more routine ones, there is likely to be greater asymmetry between the proponent and the external source than between the proponent and an internal source. The difference is likely to be less pronounced in the case of an innovation-based proposal, however, because the internal source does not have the same advantage when the project is not replicating something the firm is already doing.

The fact that external sources have some relative advantages over internal sources in the case of highly innovative proposals, combined with one of the causes of innovation - high employee mobility across firms - helps explain why highly innovative industries tend to be geographically concentrated, with most of the principal firms and external funding sources all geographically close to one another. The greater relative need for external finance makes reputation-based authority more important. Reputation-based authority is more likely to develop in an industry with high employee mobility if all persons are close to one another.

\section{Project Funding within an Established Corporation}

The top management of a large established corporation stands in the position of an intermediary in the information and decision delegation network that runs from individual savers to project proponents. Top management makes real investment decisions: which of its employees' proposed projects to implement. It also makes financial decisions: the making of distributions to shareholders (dividends, liquidating payments, and share repurchases), and the obtaining of outside financing. It also must decide what messages to emit to financial intermediaries, investment advisers, and the general investing public. In making these decisions, each member of the top management group, like most individuals, can be assumed to be personally interested in compensation, perquisites, respect, power, affection of those around him, and a sense of rectitude. He is also assumed to have a strong desire to retain his job. Management can be expected to make decisions in the ways which it perceives best further these interests, subject to the constraints within which it operates. This section will first examine the way top management receives and processes information and then the strategies it employs to make the decisions that, given its evaluation of the consequences of different actions, are the most advantageous to its personal interests. ${ }^{21}$

${ }^{21}$ What follows in the text attempts to sketch out a brief, informal theory that emphasizes an information processing and incentives perspective that fits into the larger organizational theory 
Capitalism and Society, Vol. 5 [2010], Iss. 3, Art. 1

\section{Information processing}

Bits of information relevant to the decisions of top management may have their origins inside or outside the firm. Either way, they are likely to be processed as they make their way toward the top managers of a firm. The processing has two functions: (a) to make available to the managers the expertise of other members of the organization so that managers can best estimate the probability distribution of possible outcomes from implementation of each idea, and (b) to reduce, by eliminating those least critical to the managers' decisions, the total number of information bits reaching top managers to a number they can handle. Top management is motivated to make this information collection and processing system work as well as is possible for any given level of cost.

It has already been suggested that project proponents are motivated in many situations to emit information different from what would be the most helpful to top management. The ultimate source of any other kinds of information used directly or derivatively by the top managers presents the same motivational

approach of this article. There is, of course, a huge and rich literature that cuts the investment decision by firms from a wide number of perspectives which would need to be considered to give a fuller account. Representative works include the following. JOSHEPH SCHUMPETER, THE Theory of ECONOMic DeVelopment (1934, Opie trans.); Zoltan J. Acs \& DAVID B. Audretsch, InNOVATION AND SMAll Firms (1990) ; Kathy Fogel et al., Big Business Stability and Economic Growth: Is What's Good for General Motors What's Good for America?, Available at http://ssrn.com/abstract=916547; PHILIPE AGHION \& PETER HowitT, ENDOGENOUS GROwTH THEORY (1998); Richard R. NELSON \& Sidney Winter, AN Evolutionary Theory of Economic Change (1982); M. L. Tushman and P. Anderson, Technological Discontinuties and Organizational Environments, 31 Admin. SCIENCE Q. 439 (1986), 439; Oliver WiLliamson, THE ECONOMIC INSTITUTIONS OF CAPITALISM (1985); Benjamin Klein, et al., Vertical Integration, Appropriable Rents, and the Competitive Contracting Process, 21 J. LAW \& ECON. 297 (1978); Oliver Hart, Firms, Contracts, and Financial Structure, 13-91 (1995). Clayton M. Christensen, The InNovator's Dilemma (1999); S. McDonald, Learning to Change: An Information Perspective on Learning in the Organization, 6 ORG. SCIENCE 557 (1995); T. BuMS and G. Stalker, The Management of Innovation; I. BRight, Research, DeVelopment, AND Technological Innovation; A. Rubenstein, Organization and Research and Development Decision-Making Within the Decentralized Firm, in Richard R. Nelson, ed., The Rate and Direction of Inventive Activity, pp. 385-394; E. ROBERTS, ENTREPRENEURSHIP AND Technology; Burton Klein, Dynamic Economics; A. Chandler, Strategy and STRUCTURE; W. Strassmann, The Risks of Innovation in Twentieth Century Manufacturing Methods, 5 Technology and Culture 215(1964), Oliver Williamson, Markets AND HIERARCHIES, 122 - 127; Monsen and Downs, A Theory of Large Managerial Firms, 73 in J. POL. ECON. 221 (1975), Z. Block, Can Corporate venturing Succeed?, 3 J. Business StRATEgy 21 (1982); N. Fast, A Visit to the New venture Graveyard, 22 RESEARCH MANAGEMENT 18 (1979); J. Meyer and E. Kuh, The Investment Decision (1957); C. F. CARTer and B. R. Williams, InVESTMENT IN INNOVATION (1958); R. Marris, The Corporation and Economic Theory, in R. Marris and A. Wood, eds., The Corporate Economy (1971).

DOI: $10.2202 / 1932-0213.1078$ 
Fox: Promoting Innovation: The Law of Publicly Traded Corporations

problem for top managers, as do any information intermediaries that stand between top managers and the project proponent, or other ultimate sources of information. Top management as it processes the information it receives, must utilize organizational skill to reduce the incentives for this behavior at each level and to account for the distortions that remain. In the effort to correct for bias, a certain residual amount of uncertainty is inevitable at each level through which information is gathered, analyzed and summarized as it makes its way toward top management. The larger the firm, the more such levels there will be and the greater the uncertainty by the time the information reaches the top.

For a firm whose top managers have a given level of organizational skill, the seriousness of the uncertainty generated by the possibility of manipulative information depends on the nature of the idea that the information concerns. A typical firm tends to specialize in certain areas. This specialization is reflected in the training and job histories of its personnel. And within its areas of specialty, it develops experiences and understandings of what has and has not worked in the past. This experience helps determine the firm's interest rules: which information gets attention and which does not. Thus, even within its areas of specialty, a firm tends to tolerate only a narrow range of ideas. Burton Klein, for example, concludes that this tendency explains why, when he looked at the histories of a number of industries, he found that a precondition for a period of rapid innovation was a minimum of four to eight firms accounting for 50 percent of the market. ${ }^{22}$

This combination of specialization and experience makes the firm highly sensitive to the possibilities of certain ideas. But the trade-off is that it is relatively insensitive to the possibilities of many others. A firm's narrowness is likely to take on a conservative shade as both its authority and interest rules ossify over time and block the types of information that result in innovative investment. Anthony Downs suggests as a matter of organizational theory that the older the organization, the less receptive it is to innovative ideas. ${ }^{23}$ Organizations develop rigid rules on the basis of experience and become prisoners of their past successes. Ruth Mack comes to a similar conclusion using a somewhat more complete theory. She suggests that human beings lack tolerance for actions involving what she terms "ambiguity": actions whose riskiness is difficult to evaluate. ${ }^{24}$ Because established organizations have past experience that enables them to evaluate very capably the risks associated with certain kinds of actions, intolerance of ambiguity leads them to favor such actions over innovative actions, with which by definition they have no experience. There is empirical evidence

${ }^{22}$ Burton Klein, Dynamic ECONOMics 78, 82.

${ }^{23}$ Anthony Downs, InSIDE BUREAUCRACY 18-20 (1998).

${ }^{24}$ Ruth Mack, PlanNING ON UNCERTAINTY 55-58 (1971) 
suggesting that older firms are unable to find projects in which to reinvest their earnings which are as profitable as those found by newer firms. ${ }^{25}$

\section{Decisionmaking and message emissions}

The discussion that follows relates to the top managers of established firms with dispersed ownership, a source of a very large portion of all real investment project funding in the United States. All the production, project funding and information emission decisions of these managers have the potential, directly or indirectly, to affect their personal interests. Some of the decisions which would further their personal interests may be ones that are not in the best interests of shareholders. To the extent that managers can resolve such conflicts in their own favor without significantly increasing the likelihood of the primary threats to their jobsbankruptcy and hostile takeover-they will do so. A resolution of conflict in management's favor, if detected with reasonable assurance by an outsider, may, however, demonstrate the possibility of a profitable hostile takeover. Thus, management should, in making real and financial decisions that pose such a conflict, resolve the conflict in its favor only where detection is unlikely.

Set out below is a strategy that would maximize managerial interests. The underlying premise is that managers can maximize their own interests by maximizing the free cash flow of the corporation over time discounted to present value. This guide is subject to the constraint that managers should refrain from pursing this goal beyond the point where it risks a hostile takeover by sufficiently depressing share value in an observable way. Hostile takeover becomes a risk when outsiders are able to ascertain that a substantial gap likely exists between management's course of action and what would maximize share value.

The proposition that the goal of top management is to maximize the firm's free cash flow over time discounted to present value reflects the concept that the larger the available cash flow, the greater the capacity of the firm over time to satisfy interests of each of the top managers: compensation, luxury perquisites,

\footnotetext{
${ }^{25}$ Henry Grabowski \& Dennis Mueller, Life Cycle Effects on Corporate Returns and Retentions, 57 Rev. ECon. \& Stat. 400 (1975). See Dennis C. Mueller \& S. Lawrence Yun, Rates of Return Over the Firm's Lifecycle,7 Indust. AND CORP. ChANGE, 347, 352--53 (1998) (finding that "[y]oung firms earned higher returns on investment than old ones in general"). Established firms vary, of course, in the extent, if any, to which they fall victim to these problems. Firms in lines of business where there is a high rate of technical change are, by the very nature of the kinds of ideas they are specialized in assessing, more likely to find and implement positive NPV projects. Firms with substantial R\&D budgets appear to do better because internally generated ideas are more likely to get favorable attention. Structural innovations such as corporate venturing can sometime help. Particularly well led firms may also self-consciously try to organize in ways to overcome the tendency of established firms to develop the problems discussed in the text.
} 
Fox: Promoting Innovation: The Law of Publicly Traded Corporations

respect, power, affection of those around him, and a sense of rectitude. A "diversion" of a certain absolute amount from the available cash flow in any one period to pay greater compensation, and provide more perquisites, than is competitively necessary is a smaller percentage of a large available cash flow than of a small one. ${ }^{26}$ Thus it is harder to detect. The same is true of a diversion of a given amount to engage in an activity which gives top management a sense of rectitude for "doing good" but which does not contribute to firm profitability. This goal also implies, after deduction for management compensation and expenses, the largest possible growth in firm assets (subject, of course, to the constraint that each project invested in is not expected to lose money). The larger the firm's assets, the greater the respect and power that attaches to a top management job. ${ }^{27}$ The greater the rate of growth of the assets, the more frequent the opportunities for promotion, thereby improving the relations between top managers and those directly below them. ${ }^{28}$

The strategy is as follows. How far top management can successfully pursue this strategy depends on the larger institutional and legal framework within which the established firm operates.

1. The debt/equity ratio should be kept low. A lower debt/equity ratio reduces the risk of job loss through bankruptcy and increases free cash flow. ${ }^{29}$

2. The firm should have the best information generating and processing functions possible for any given level of cost in order to identify the best new investment project proposals. It should use the predictions derived from these functions to identify a list of the best investment opportunities that can be found according to expected rates of return adjusted for systematic risk.

3. The firm should retain as high a percentage of cash flow as shareholder pressure will permit, and make investments going down the list of opportunities as far as the money retained will take the firm. It should do so even if some or all

\footnotetext{
${ }^{26}$ See Javier Gabaix \& Augustin Landier, Why Has CEO Pay Increased So Much?, 123 Q. J. ECON. 49, 67-70 (2008) ("[B]oth aggregate firm size and individual firm size appear to be strongly significant determinants of CEO compensation." with compensation increasing with firm size); George P. Baker, Michael C. Jensen, and Kevin J. Murphy, Compensation and Incentives: Practice vs. Theory, 43 J. FIN. 593 (1988) (noting that "a 10 percent larger firm will pay its executives an average of 3 percent more"); Kevin J. Murphy, Corporate Performance and Managerial Remuneration: An Empirical Analysis, 7 J. ACCT. \& ECON. 11, $32-37$ (1985) (finding that a firm whose sales increase will increase its CEO's salary and bonus).

${ }^{27}$ The idea that managers gain utility simply from the size of the firm they run has a long history. See, for example, Frank Knight, Risk, Uncertainty, AND Profit (1921); JosePH A. Schumpeter, The Theory of ECONOMic Development; Robert A. Gordon, Business LEADERSHIP IN THE LARGE CORPORATION (1945).

${ }^{28}$ Oliver Williamson has argued that expansion is an effective way of settling disputes among managers. OLIVER WILLIAMSON, MARKETS AND HIERARCHIES 120.

${ }^{29}$ See, e.g., Michael Jensen, The Takeover Controversy: Analysis and Evidence, THE REvolution IN CORPORATE FinANCE (Joel M. Stern \& Donald H. Chew Jr. eds., 3d ed. 1998).
} 
of the projects have negative NPVs, i.e., have risk-adjusted expected rates of return less than the rate at which shareholders on average could earn on the money in the market if returned to them. As long as the project has an expected return greater than zero, it will still add to the value of the firm's expected free cash flow over time. If, after going down the list and exhausting its retained cash flow, the firm still has unimplemented positive NPV projects, it should raise external funds to implement these projects as well, assuming that the cash outflow discounted to present value associated with the terms of the financing is less the cash inflow from having invested in the project discounted to present value. ${ }^{30}$

4. This strategy may not be in the best interests of shareholders, since it contemplates the possibility of investing in negative NPV projects. Top management should therefore minimize, for any given level of corporate performance, the chance of hostile takeover. They can minimize this risk by consistently issuing predictions relevant to future distributions to shareholders that are as accurate as possible, but doing so in highly conclusionary form (i.e., without giving the facts on which the predictions are based). They should issue as little other information about the corporation as possible. This combination of accurate predictions with minimal substantive disclosure minimizes the kind of information asymmetry that results in share price being discounted in the capital markets, while not providing the kind of information that would lead to reductions in the agency costs of management. This strategy is aided by avoiding outside financing, especially publicly issued equity, unless it would permit the firm to invest in a positive NPV project, because the use of external finance tends require additional disclosure. ${ }^{31}$

\section{E. Project Funding from Financial Intermediaries}

If a project proponent seeks funding for a new project directly from an outside source and does not go directly to actual individual investors ("angel investors"), the two likely sources are a bank or a venture capital firm. Each of these financial intermediaries is motivated, like the top management of an established firm, to have the best information generating and processing functions possible for any given level of cost, in order to identify the best new investment opportunities available to it.

\footnotetext{
${ }^{30}$ External financing can be expensive because of the information asymmetries between management and external capital sources. These asymmetries may be particularly great with respect to the prospects of novel investment projects. Stewart C. Myers \& Nicholas S. Majluf. Corporate Financing and Investment Decisions When Firms Have Information that Investors do not Have, 13 J. FIN. ECON. 187 (1984).

${ }^{31}$ See Frank Easterbrook, Two Agency-Cost Explanations of Dividends, 74 AM. ECON. REV. 650 (1984).
}

DOI: $10.2202 / 1932-0213.1078$ 
Fox: Promoting Innovation: The Law of Publicly Traded Corporations

Unlike established firm top management, however, neither of these financial intermediaries is likely to be tempted, in order to maximize growth and size, to extend funds on terms that would make any of its investments negative NPV propositions. This is because top managers of established firms with more free cash flow than positive NPV projects into which to invest have funds derived from non-redeemable equity. Banks, on the other hand, obtain most of their funds not from equity but from deposits and certificates of deposit that are subject to redemption or must be rolled over frequently. The shares of venture capital firms are also typically redeemable after a certain point in the life of the firm. In addition, their managers typically will want to form new funds, which puts a high premium on the returns they make on their existing funds.

The structure of the terms on which funds are extended by banks differs greatly from this structure with respect to venture capital firms. This difference makes a venture capital firm a far more promising source for funding innovative projects than is a bank.

\section{Banks}

The terms on which banks extend loans involve repayment of fixed principal plus interest, which may or may not be paid depending on the outcome of the project. The only way to compensate for the risk of less than full repayment is for the terms to provide for a higher rate of interest. As Stiglitz and Weiss have explained, given the information asymmetry between the proponent and the bank as the funding source, an adverse selection problem is created that leads to credit rationing and the rational refusal to fund positive NPV projects. ${ }^{32}$ This credit rationing problem is accentuated in the case of a highly innovative project proposal because the information asymmetry will typically be greater with such proposals. Banks also rely more on collateral, which the real investment uses of funding for a highly innovative project are less likely to provide. ${ }^{33}$ Given the availability of the venture capital alternative, the relative disadvantage of banks as funders of highly innovative projects is self reinforcing because bank personnel will not find it rewarding to specialize in assessing these kinds of investment opportunities and will gain skill from experience. ${ }^{34}$ Bank personnel are also less

\footnotetext{
${ }^{32}$ Joseph E. Stiglitz \& Andrew Weiss, Credit Rationing with Imperfect Information, 71 AM. ECON. REV. 393 (1981).

33 Masako Ueda, Banks versus Venture Capital: Project Evaluation, Screening, and Expropriation, 59 J. Fin. 601 (2004).

${ }^{34}$ Atanassov, Nanda and Seru find that U.S. firms that rely on relationship banking as their funding source are less innovative as measured by patent data than those that rely on equity or publicly issued debt. They hypothesize that this result is due in part to bank personnel being unable to evaluate novel technologies. Julian Atanassov, Vikram Nanda \& Amit Seru, Finance
} 
able to make such assessments because the structure of the terms on which banks extend financing does not make it sensible for banks to offer hands on ongoing monitoring and management advice. Because their terms do not involve such requirements and services, bank officers do not acquire the intimate knowledge about given high tech industries that adds to their abilities to assess new proposals. $^{35}$

\section{Venture capital}

Venture capital avoids the banks' adverse selection problem of fixed payments by instead extending funding on terms that typically involve convertible preferred stock. The typical package also includes control rights in the form of positions on the board of directors to which the fund has rights. Staged financing also helps give the funds control. These features are designed to help deal two problems. One is the information asymmetry problem between the proponent and the funding source. Second is the fact that the proponent is offering, as a package, an investment idea and his still untested management skills. Gilson and Black have shown how the optimal venture capital contract is structured around the availability of the venture capitalist's exit through an initial public offering (IPO). ${ }^{36}$ The availability of this mode of exit resolves the "two sided moral hazard problem." One side of the problem derives from the fact that the fund needs control rights to protect against the proponent running the company at the expense of the fund. The other side derives from the fact that the proponent, having given these control rights, needs protection against a hold up. The availability of an exit via an IPO also provides the venture fund manager a way of showing current and future investors the profitability of their investments. In addition, by facilitating the "recycling of funds," the availability of IPO exit also allows the fund managers to maximize the rents earned from their special skills at identifying promising projects and at guiding fledgling managers.

Black and Gilson use this thesis to explain why innovation based start-ups occur in much greater numbers in the United States than in Germany or Japan. According to their thesis, the existence of a more vibrant public equity market in the United States makes this optimal form of venture capital contract more available in the United States than elsewhere. This thesis has spawned a

and Innovation: The Case of Publicly Traded Firms (2007)

http://ssrn.com/abstract $=740045$.

${ }^{35}$ Andrew Winton \& Vijay Yerramilli, Entrepreneurial Finance: Banks vsersus Venture Capital. http://ssrn.com/abstract=994630.

${ }^{36}$ Bernard S, Black \& Ronald J. Gilson, Venture Capital and the Strucutre of Capital Markets: Banks versus Stock Market, 47 J.FIN.ECON. 243 (1996). 
Fox: Promoting Innovation: The Law of Publicly Traded Corporations

considerable literature, much of it affirmatively refining Black and Gilson's basic observations. 37

\section{MACRo AnALYSIS}

The preceding micro analysis investigated how the various parts of a market based financial system work to make any particular project choice decision. The question addressed here is how the system works as a whole. The macro analysis starts with the proposition that every economy, whether centralized, pure market, or otherwise, needs a process which takes account of information held by disparate sources in order to decide which real investment projects shall receive society's scarce savings. The goal that we want this process to serve is enhancing the capacity of the economy's system of finance to identify and implement the most promising investment projects to the extent that doing so is cost effective and consistent with maintaining production and output choice efficiency.

The task of the finance process choosing among real investment proposals is one of discovery. Technological possibilities change with each passing time period. In the end, the quality of the decisions is ultimately determined by how the system handles information. The system has rules for handling information, but is capable of modifying these rules with experience through feedback. In doing so, it can steer itself toward the goal of finding the best projects and can be judged by how well it does so.

\section{A. Communications Rigidity}

Organizational theorists have identified a variety of pathologies that commonly afflict simple hierarchical organizations. ${ }^{38}$ Most of these pathologies can be

\footnotetext{
${ }^{37}$ A fuller account of the role of venture capital beyond the brief sketch presented in the text would require a discussion of this literature. See Samuel Kortum \& Josh Lerner, Assessing the Contribution of Venture Capital to Innovation, 31 RAND J. ECON. 674 (2000); Ronald J. Gilson, Engineering a Venture Capital Market: Lessons from the American Experience, 55 STAN. L. REV. 1067 (2003); Ralph Becker and Thomas Hellmann, The Genesis of Venture Capital - Lessons from the German Experience (2003); Bronwyn H. Hall. The Financing of Researach and Development, 18 Oxford Rev. Of ECON. POLICY 35 (2002); D. Gordon Smith, Venture Capital Contracting in the Information Age, 2 J. SMAll \& EMERging Bus. L. 133 (1998); Manuel A. Utset, Reciprocal Fairness, Strategic Behavior \& Venture Survival: A Theory of Venture Capital-Financed Firms, 2002 Wis L. ReV. 45 (2002), Paul Gompers \& Josh Lerner, The Use of Covenants: An Empirical Analysis of Venture Partnership Agreements, 39 J.L.\& ECON. 463 (1996); Ronald Gilson \& Joseph Bankman, Why Start-ups?, 51 STAN L. REv. 289 (1999); Curtis J. Milhaupt, The Market for Innovation in the United States and Japan: Venture Capital and the Comparative Corporate Governance Debate, 91 Nw. U. L. REV. 865 (1997).
} 
classified as aspects of what we might call "communications rigidity." Communications rigidity is the result of an overemphasis on efficiency of communication rather than the efficiency of the organizational performance as a whole. Efficiency of communication requires the minimum number of bits of information to be passed from one participant to another and the minimum amount of original input on the part of each participant (thus, by this definition, an organization which has much routine passing of messages and documents from one participant to another might still be called communications efficient).

There seems to be a natural tendency for an organization to acquire communications rigidity to the extent that there are not forces to prevent it. The system fails to react to changes in environment, including good new ideas, because the organization uses routine communications methods. Such methods employ highly selective authority and interest rules and highly informationdigestive symbols. As a result, these mechanisms screen out information concerning changes in the environment or prevent such information from reaching those persons who could most appreciate its implications. ${ }^{39}$ If the system does not have an adequate feedback process, these failures are not recognized and corrected.

It is possible for the finance process in an economy to display such communications rigidity. The system could be very communications efficient in the sense of using a relatively small amount of real resources for information gathering, processing and transmission. In a world where the pace of scientific discovery is slow, such communications efficiency might be ideal. The savings in real resources devoted to information would not come at an undue cost in terms of other measures of organizational performance. But where there is a rapid rate of scientific discovery translatable into new products and processes, a high level of communications efficiency presents serious problems. Whether an economy in such a world in fact suffers from such a problem depends on the effectiveness of the system's feedback process, which in turn is related to the legal and cultural environment in which it operates.

\section{B. A World of Slow Change Minimizes Potential System Failures}

The finance process could exhibit three possible kinds of failures in terms of finding and implementing the most promising investment projects: (1) not choosing for implementation, from among all proposed projects, those that are the most promising according to the best evaluations being made, (2) not making the

\footnotetext{
${ }^{38}$ See generally, KARL DeUTSCH, Nerves of Government (1963); Mack, supra note 24 ; Downs supra note 23; HAROLD WILENSKY, ORGANIZATIONAL INTELLIGENCE 94-109 (1968).

${ }^{39}$ JAMES MARCH \& HERBERT SiMON, ORgANIZATIONS 164 (1958).
} 
Fox: Promoting Innovation: The Law of Publicly Traded Corporations

best possible evaluations of the prospects of all proposed projects, and (3) having operating costs that, at the margin, are in excess of the benefits that the system confers upon the economy. In a world of slow change, however, a system dominated by internal finance, supplemented perhaps by close, well established relationships between firms and their principal banks, is likely to perform reasonably well along all three of these dimensions. As will be discussed subsequently, in a world of fast change, a finance process with these attributes is likely to exhibit significant failures along the first two dimensions of performance and enjoy a kind of false economy with respect to the third.

\section{Failure to use the best available evaluations}

An organization may be structured such that its decision whether or not to undertake any particular action does not correspond to what is suggested, given the system's goals, by the best evaluation being made in the system concerning the consequences of the action. In the case of an economy's finance process, this could happen if firms have a strong internal finance bias. Many firms may be implementing projects that their future cash flow evaluations show are negative NPV projects. ${ }^{40}$ The amounts invested in these negative NPV projects are amounts not paid out into the markets as dividends. Since society's savings are scarce, the implementation of these negative NPV projects crowds out proposed projects of other firms that have been assessed by these other firms as having greater net present value. ${ }^{41}$

In a world of slow change, however, a system dominated by internal finance would not likely seriously display this first type of failure. Consider the kind of new project that is likely to be proposed in a world of slow change: a replacement of, or an addition to, a similar project already existing in the economy. Changes in demand and factor supplies are gradual. Product or process

\footnotetext{
40 These are negative NPV projects based on the lower discount rate that would reflect the project's undiversifiable risk in a world where there were no other firms displaying this behavior, rather than based on the inflated discount rate that they actually face, because many other firms do in fact display such behavior.

${ }^{41}$ This crowding out occurs as follows: because the dividends are not paid out, there are fewer dollars in the market competing to purchase the rights to future expected cash flows. These future cash flows will be priced lower than would otherwise be the case. This inflates the discount rate. The firms that forgo implementing more worthwhile projects are ones that have a sufficient number of promising investment project proposals, relative to their internally generated funds, that not all their promising projects can be internally funded. To maximize share value, these firms will need to use this inflated discount rate to calculate the NPV of any project that they cannot fund internally. As a result, the firms with a surplus of good projects will not implement proposed projects that would be positive NPV projects at the discount rate that would have prevailed if the foregone dividends of firms with a deficiency of good projects had been paid, but that are negative NPV projects using the inflated discount rate.
} 
improvements are minor because that is all the rate of scientific advance permits. A replacement of, or extension to, a project already existing in the economy is most likely to be proposed by an employee to the top management of the firm holding the existing project. A firm that operates in a market with a gradually increasing demand or which has a superior record of figuring out minor product or process improvements will have a list of projects which are superior to those of a firm with the opposite characteristics. It will also be more profitable. Thus, in a world of slow change, the distribution of profits anticipates the evaluator's evaluations. The most funds automatically go to the evaluators who are being presented the most promising projects to evaluate.

The story applies as well to a finance process where internal finance is supplemented by well-established, close banking relationships. In a world of slow change, the types of historical data concerning cash flows and asset values on which its lending decisions are likely to be based are reasonably reliable predictions of future cash flows.

Even where the match between internally generated funds and good project proposals for some firms is sufficiently off that firms seek outside equity, this first potential system failure is unlikely to be a serious problem in a world of slow change. The price of an equity offering by such a firm will be based predominantly on the price at which its already outstanding shares trade in the secondary market. Under the efficient market hypothesis, this price will reflect the knowledge of the best informed investors concerning the evaluation skills of incumbent managers, evaluation skills that have been tested by experience. Consider a situation in which a firm's top managers are good evaluators and these managers assess that the firm has more promising projects than it can fund internally. These positive facts are likely to be reflected in the share price at which the shares can be offered, thereby making the offering to finance the project financially worthwhile. As for firms that have more internally generated funds than promising investment opportunities, any tendency by management to retain these funds to invest in unpromising projects will be more easily detected in a world of slow change because, compared to a world of fast change, there are fewer alternative explanations for poor returns over time.

\section{Failure to make the best evaluations possible}

An organization may also be structured such that information relevant to predicting the consequences of an action is not sent to the persons most capable of making these evaluations. In the case of an economy's finance process, this would mean a failure to send information concerning the prospects of a proposed investment project to the person most capable of evaluating its prospects. 
Fox: Promoting Innovation: The Law of Publicly Traded Corporations

In a world of slow change, however, a system dominated by internal finance is also unlikely seriously to display this second type of failure. In the case of most project proposals, information concerning the project goes, already highly summarized, to just one recipient - the top management of the firm employing its proponent - and very little of what is received by top management is passed on to finance process participants outside the firm. Such a parsimonious pattern of information handling is usually fully appropriate in a world of slow change. In such a world, the questions that need to be answered are well defined. Decisions can be based on a program relating stimuli to appropriate response which feedback processes have shown to work well in the past. The communications system can employ well-recognized symbols that incorporate a great deal of information. Authority rules will allow participants in the system to be very selective in the information to which they pay attention, because it is easy to assume the competence and integrity of an information source in the current situation if these attributes have been demonstrated many times before in similar past situations. The same is true for interest rules because experience tells the participant that it is safe to ignore messages of many kinds of content. ${ }^{42}$

The small number of people to which information goes with respect to any proposed project are in fact the ones who, in a world of slow change, are likely to be the best able to use it. The top managers of the firm employing the proponent, because of their familiarity with the firms' existing projects, will have an inherent advantage in evaluating the proposed project. Since demand, factor supplies, and technology change slowly, they also know well the environment in which the project would operate. The organizational winnowing of information and its summarization in conclusory language before it reaches the top managers is likely to be rational for the same reasons that past experience will be highly relevant to the current situation.

The story again carries through to the extent that internal finance is supplemented by a well established, close banking relationship. In a world of slow change, a bank with which the firm has a close relationship is in a similar position with respect to the firm's top managers as these top managers are with respect to the project proponents.

\section{Cost in excess of benefits}

Information processing by the finance process uses real resources. A system of finance dominated by internal finance, perhaps supplemented by lending from banks with which firms have close, established relationships, is, by its very parsimony in the use of information, the least costly approach. Thus it is unlikely

${ }^{42}$ Deutsch, supra note 38, at 170. 
to display the third potential system failure: costs in excess of benefits. In a world of slow change, its low cost is also unlikely to represent a false economy since the system is likely to perform well along the other dimensions of system performance.

\section{A World of Fast Change}

In contrast to the world of slow change, an internal finance dominated finance process, supplemented perhaps by close bank relationships, might well exhibit significant failures along the first two dimensions of system performance - using the best evaluations being made and making the best evaluations - in a world where scientific advances are rapid. The lower cost of such a finance process may be a self-reinforcing false economy.

\section{Using the best evaluations}

Consider first using the best available evaluations. There is no mechanism in the world of fast change akin to the one in the world of slow change where the profits of a firm anticipate the quality of a firm's list of proposed projects. In particular, there is no reason to believe that a firm possessing a good and innovative project idea will have corresponding profits to finance the idea internally. Empirical study supports the proposition that rapidly innovating companies are more likely to require outside financing. ${ }^{43}$ There is also evidence from earlier decades in the United States that firms that relied entirely on internal finance invested in projects with substantially lower returns than what shareholders could earn in the market if the cash flows of these firms had been returned to them. ${ }^{44}$

\footnotetext{
${ }^{43}$ See, e.g., James Brown, Steven Fazzari \& Bruce Petersen, Financing Innovation and Growth: Cash Flow, External Equity, and the 1990s R\&D Boom, 64 J. Fin. 151 (2009) ("[Y]oung high-tech firms typically exhaust internal finance and issue stock as their marginal source of funds").

${ }^{44}$ See, e.g., Michael Jensen, The Takeover Controversy: Analysis and Evidence, THE REVOLUTION in Corporate Finance (Joel M. Stern \& Donald H. Chew Jr. eds., 3d ed. 1998). Gordon DONALDSON, CORPORATE DEBT CAPACITY (1961); William J. Baumol et al., Earnings Retention, New Capital and the Growth of the Firm, 52 ReV. ECON. \& STAT. 345 (1970). For a critical review of these and several other studies, along with an estimate of the magnitude of the effects on the economy, see Merritt B. Fox, Finance and Industrial Performance: Theory, Practice AND POLICY 233-37 (1988). See also Reinier Kraakman, Taking Discounts Seriously: The Implications of "Discounted" Share Prices as an Acquisition Motive, 88 Colum. L. REV. 891, 898 (1988).
}

DOI: 10.2202/1932-0213.1078 
Fox: Promoting Innovation: The Law of Publicly Traded Corporations

\section{Making the best evaluations}

The even bigger problem, however, may be the failure to get information concerning proposed projects to those best able to evaluate them. To see why, let us start with some very abstract observations, treating the finance process as a single organization and equating its ability to find new promising projects to its ability to innovate. Innovation involves the search for alternatives and evaluation of their expected consequences if pursued. The capacity of an organization to innovate relates to its ability to rearrange items of information into new patterns and identify the occasions when a particular rearrangement would be useful. ${ }^{45}$ The fewer and more aggregated the pieces of information that flow through the system, the fewer the possible rearrangements. For new ideas to make it through the communication channels, the symbols used must aggregate less information and the authority and interest rules must be less selective. A large portion of the participants who have significant impact on the organization's decisions should themselves be sensitive to new ideas, i.e., their internal information processing structures should have characteristics resembling those desirable for innovative organizations. The environment in which they operate should encourage this sensitivity. A number of persons, with differing backgrounds, personal information processing structures, and tastes for risk, should have the opportunity to act on the basis of the same idea, not just one. Operating in an uncertain environment can also give rise to innovation because the stress involved, by making "satisficing" unviable, leads to the questioning of old truths.

Less autonomy on the part of individual decision makers, while normally thought to stifle creativity, can, in a certain form, engender it. If one is required to look outside to seek the assistance of a continuously changing list of others, one is more challenged and exposed to new ideas. Communications theory suggests a number of reasons why autonomy can be inversely related to the capacity for innovation. Through habit, autonomous groups tend to overvalue parochial or internal sources of information. They block out information from sources with wider ranges of experience, since nothing forces them to have contact with such sources. ${ }^{46}$ As a general matter, groups have a bias to let things stay as they are because it is easier to agree to let things stay as they are than to agree to institute one of several possible changes.

Autonomy reinforces this tendency by allowing those involved to avoid constraints imposed by outsiders that would prevent the solution currently in use from continuing to be workable. Advancement within an autonomous group is more likely to go to an "organization man" who focuses inwardly on the existing internal rules of the group and on how to use them to his advantage rather than to

\footnotetext{
${ }^{45}$ Deutsch, supra note 38, at 108-109 163-165, 172-176.

${ }^{46}$ Id., Burton Klein, supra note 21, at 143-144; Mack, supra note 24, at 150-163.
} 
a person who focuses on establishing his worth by taking actions that result, directly or indirectly, in reactions by persons outside the group that benefit the group.

\section{Self reinforcing tendencies}

Both high and low levels of innovative behavior by an organization are selfreinforcing. If an organization undergoes only slow change for a period of time, the components that succeed are ones that are well adapted to slow change, i.e., those that display a high level of information efficiency. The components that are well adapted for fast change, which are the likely sources of future innovation, have information processing systems that are too costly to survive. Those that remain have a vested interest in maintaining slow change. Conversely, if an organization undergoes fast change for a period of time, the components that succeed are the ones which are well adapted to fast change so there will be many sources of future innovation. Each component will be operating in an environment of uncertainty, and each is likely to have limited autonomy. Therefore, an organization's level of innovativeness may be more a product of its past than of outside forces that move it toward some optimal trade-off between innovativeness and communications efficiency.

\section{Applying the Macro Analysis to Designing the Finance Process}

What does the macro analysis suggest about the best design for a finance process that would be sensitive to innovative new project proposals? A system that resembles the U.S. in the 1970s and 1980s is very communications efficient: most investment decisions are made internally without need to raise money from outside capital markets and there is not much hostile takeover pressure. ${ }^{47}$ The bulk of all project proposals in such a system are made by employees of existing firms who communicate their proposals to mangers who know them well. Little information needs to leave the firm since little outside finance is being sought.

As discussed, this information efficiency would be a good thing in a world of slow change. Firms with the most internal funds are the ones that are likely to be considering the most promising investment project proposals. The top managers who evaluate proposals can use rules that have been shown to work well in the past. The system is low cost compared to the alternative of cycling more funds through external capital markets. More use of external equity markets simply risks the costs of split information, i.e. proponents in each firm know well the prospects of their proposals but outsiders do not. External funding sources

${ }^{47}$ See Part VI for a full discussion of the characteristics of the U.S. finance process at that time. 
Fox: Promoting Innovation: The Law of Publicly Traded Corporations

either need to expend a lot to make up for this deficit, or make mistakes whereby the wrong projects get funded.

This information efficiency may be too costly in terms of dynamic efficiency in a world with the potential for faster technical change, however. For the finance process to be more innovative, it needs the ability, as just discussed, to rearrange items of information into new patterns and identify the occasions when a particular rearrangement would be useful. For new ideas to make it through the system, the symbols used must aggregate less information. Because people vary in what they will be sensitive to, proposed projects need the opportunity to be exposed to multiple evaluators. People making decisions should not be narrow experts. Because people can learn from one another, decisions should not be made by persons with too much autonomy, i.e. where each decision-maker has a narrow defined clear zone of authority. Also there are benefits to operating in a somewhat uncertain environment: stress leads to the questioning of old truths.

This analysis suggests that a finance process with the following characteristics would be more sensitive to the potential of innovative investment project proposals.

1. An active market for corporate control

2. Relatively high payouts to investors of the cash flows of established corporations

3. A substantial venture capital sector

4. An active market for IPOs

5. Relatively accurate share prices in primary and secondary market.

Put in different terms, the foregoing theoretical analysis suggests that a vital and well-functioning equity market with relatively accurate share prices and relative transparency concerning the businesses of its issuers will promote innovation. Thus a legal regime that promotes high disclosure is important. Such a system plays a key role in disciplining management of established firms to find the best projects they can and to pay out the rest in cash and in directing external equity to the best places.

Consider first improved price accuracy in the secondary market and the disclosure that induces it. Disclosure and more accurate secondary market share prices enhance the effectiveness of the social devices that limit the extent to which managers of established public corporations place their own interests above those of their shareholders (the agency costs of management). To start, additional disclosure and increased share price accuracy, by signaling when there are problems, assist in both the effective exercise of the shareholder franchise and shareholder enforcement of management's fiduciary duties. ${ }^{48}$ They also increase

\footnotetext{
${ }^{48}$ See Merritt B. Fox, Required Disclosure and Corporate Governance, in 62 L. \& CONTEMP. PROBS. 113 (1999). This is obvious when disclosures themselves suggest the possible existence
} 
the threat of hostile takeover when managers engage in non-share-valuemaximizing behavior. The additional disclosure and more accurate prices make a takeover less risky for potential acquirers and reduce the chance that a valueenhancing acquisition will be deterred by the target having an inaccurately high share price. ${ }^{49}$ Finally, by reducing the riskiness associated with holding an issuer's stock in a less than fully diversified portfolio, additional disclosure increases the use of share price-based management compensation, which also helps align the interests of managers and shareholders. ${ }^{50}$

In terms of the potential pathologies of established firms, a well functioning equity market, by adding stress and both positive and negative incentives, will reduce the number of promising opportunities that are missed because of managerial risk aversity or unquestioned rigid processing rules. It will also be more likely to result in the payout of cash rather than its investment in negative NPV projects.

What is also needed is an active market for new share offerings. Elements required for this include, again, transparency and price accuracy. Improved price accuracy in the primary market for shares produces these social benefits directly. For issuer offerings, greater share price accuracy at a time when an issuer contemplates implementing a new project by means of a new share offering will bring the issuer's cost of capital more in line with the social cost of investing

of such a problem. It can also occur when a share price declines, indicating, if the price has a relatively high level of accuracy, that something is amiss.

${ }^{49}$ The market for corporate control is a well-recognized device for limiting the agency costs of management where ownership is separated from control, as in the typical publicly traded corporation with dispersed ownership. More information and the resulting increase in price accuracy improves the control market's effectiveness in performing this role. A potential acquirer, in deciding whether it is worth paying what it would need to pay to acquire a target that the acquirer feels is mismanaged, must make an assessment of what the target would be worth in the acquirer's hands. This assessment is inherently risky and acquirer management is likely to be risk averse. Greater disclosure, however, reduces the riskiness of this assessment. Hence, with greater disclosure, a smaller apparent deviation between incumbent management decision-making and what would maximize share value is needed to impel a potential acquirer into action.

Also, when share price is inaccurately high, even a potential acquirer that believes for sure that it can run the target better than can incumbent management may find the target not worth paying for. The increase in share price accuracy that results from greater disclosure reduces the chance that a socially worthwhile takeover will be thwarted in this fashion.

Greater disclosure thus makes the hostile takeover threat more real. Incumbent managers will be less tempted to implement negative net present value projects in order to maintain or enlarge their empires, or to operate existing projects in ways that sacrifice profits to satisfy their personal aims. Those that nevertheless do these things are more likely to be replaced. See, Fox, FINANCE AND INDUSTRIAL PERFORMANCE, in A DYNAMIC ECONOMY: THEORY, PRACTICE, AND POLICY 84-91 (1987) (hereinafter Fox, Finance and Industrial Performance).

${ }^{50}$ Merritt B. Fox, Securities Disclosure in a Globalizing Market: Who Should Regulate Whom, 95 MicH. L. REV. 2498, 2548-50 (1997). 
Fox: Promoting Innovation: The Law of Publicly Traded Corporations

society's scarce savings in the contemplated project. As a result, these savings are allocated more efficiently, going more consistently to the most promising proposed projects in the economy. ${ }^{51}$ Also needed for a vital new offering market is effective limits on the private benefits of control - i.e., good corporate law.

Primary offerings take on even more importance than I have suggested so far, however, because of the intimate relationship between an effective venture capital market for funding innovative investment projects and initial public offerings (IPOs). Start-ups typically receive their initial financing from a venture capitalist, not from a public offering of shares. Gilson and Black, as discussed earlier, have proposed, however, the provocative thesis that the optimal contract is structured around the availability of the venture capitalist's exit through aninitial publicoffering (IPO). ${ }^{52}$ Price accuracy in the venture capital exit IPO market is especially important. For venture capitalists, the prospect that the best ventures ex post will be identified accurately at time of the venture capitalist's exit adds to the incentive ex ante to find the best investment project ideas to fund. Accurate pricing of venture exits also gives more resources for reinvestment in new projects to those venture capitalists who have proved their skills by having chosen good investment projects in the past.

\section{CRUDE EMPIRICISM}

The theoretical story told here is that in an economy where equity markets and their prices play a substantial role, the finance process - the system that links savers to real investment - is more hospitable to investment in productivitypromoting innovative investment. In an era of rapid scientific advance, such a finance system, the theory suggests, will lead to greater improvements in economic welfare. We will examine four moments in economic history: the United States in the 1970s and 1980s, Japan since 1995, continental Europe since the 1995, and the United States since the 1995, to see if this story seems to have some empirical reality.

\footnotetext{
51 Merritt B. Fox, Retaining Mandatory Disclosure: Why Issuer Choice is Not Investor Empowerment, 85 VA L. REV. 1335, 1358-63 (1999).

${ }^{52}$ Bernard S, Black \& Ronald J. Gilson, Venture Capital and the Structure of Capital Markets: Banks versus Stock Market, 47 J.FIN.ECON. 243 (1996).
} 
Capitalism and Society, Vol. 5 [2010], Iss. 3, Art. 1

Table 1 - Productivity Measures versus Capital Deepening

\begin{tabular}{|l|l|l|l|l|}
\hline & $\begin{array}{l}\text { U.S. 1970- } \\
1990\end{array}$ & $\begin{array}{l}\text { U.S. } \\
1995-2008\end{array}$ & $\begin{array}{l}\text { Japan 1995- } \\
2008\end{array}$ & $\begin{array}{l}\text { Europe 1995- } \\
2008\end{array}$ \\
\hline $\begin{array}{l}\text { GDP per hour } \\
\text { worked growth } \\
\text { rate }\end{array}$ & $1.5 \%^{\mathrm{a}}$ & $2.1 \%^{\mathrm{a}}$ & $1.8 \%^{\mathrm{a}}$ & $1.3 \%^{\mathrm{b}}$ \\
\hline $\begin{array}{l}\text { Output per hour } \\
\text { worked in } \\
\text { manufacturing } \\
\text { growth rate }\end{array}$ & $2.9 \%^{\mathrm{c}}$ & $4.9 \%^{\mathrm{c}}$ & $3.3 \mathrm{o}^{\mathrm{c}}$ & $2.5 \%^{\mathrm{d}}$ \\
\hline $\begin{array}{l}\text { Real investment } \\
\text { as a percentage of } \\
\text { GDP }\end{array}$ & $20.5 \%^{\mathrm{e}}$ & $19.2 \%^{\mathrm{f}}$ & $26.2 \%^{\mathrm{f}}$ & $20.1 . \%^{\mathrm{g}}$ \\
\hline
\end{tabular}

a. Averge annual compound rate. OECD Fact Book 2010: Economic, Social and Environmental Statistics. The compound annual rate for 1995-2004 was 2.5\%. OECD Productivity Database. July 2005.

b. Average annual compound rate. This rate is derived from a simple average of the compound rates of $1.7 \%, 1.5 \%$ and $.6 \%$, respectively, for France, Germany and Italy, the three largest continental European economies. OECD Fact Book 2010: Economic, Social and Environmental Statistics. The compound annual rate for the Eurozone (the EU 15 excluding Denmark, Sweden and the UK) was 1.4\% for 1995-2004. OECD Productivity Database. July 2005.

c. Average annual compound rate. U.S. Bureau of Labor Statistics. Supplementary Tables: International Comparisons of Manufacturing productivity and unit labor cost trends 17 countries or areas, 1950-2008. October 22, 2009.

d. Average annual compound rate. This rate is derived from a simple average of the average compound rates of $3.3 \%, 3.7 \%$ and $.4 \%$, respectively, for France, Germany and Italy, the three largest continental European economies.

e. Figure is the average of the annual percentage, for each year from 1980 to and including1990, for real investment as a percentage of GDP. Data is from IMF The World Economic Outlook Database, 2008. Data before 1980 was not available.

f. Figure is the average of the annual percentage, for each year from 1995 to and including 2008, of real investment as a percentage of GDP. Data is from IMF The World Economic Outlook Database, 2008.

g. Figure is derived from the simple average of $19.8 \%, 20.0 \%$ and $20.6 \%$, respectively, for France, Germany and Italy of each country's average annual percentage, for each year from 1995 to and including 2008, of real investment as a percentage of GDP. Data is from IMF The World Economic Outlook Database, 2008. 
Fox: Promoting Innovation: The Law of Publicly Traded Corporations

\section{A. Evidence of Innovation-Based Productivity Gains}

Table 1 reveals that, of the four moments in economic history under examination, the United States since the mid-1990s is the one with the greatest growth in GDP per hour worked and manufacturing output per hour worked. These differences, if continued over time, are important in terms of long run economic welfare. At the U.S. 2.1\% growth rate, GDP per hour worked doubles in 33 years, whereas at the $1.3 \%$ average rate of the major continental European economies, it will go up by only about half.

Table 1 also suggests that these productivity gains are the result of innovation, not capital deepening. Of the four moments in economic history under examination, the one with the least capital deepening is the United States since the mid-1990s. Particularly striking is the contrast with Japan, which has been pouring a third more of its GDP every year - a full extra 7\% of GDP every year that would otherwise be available for current consumption - into real investment, but obtaining lower gains in productivity growth per hour worked than the United States in the post-1995 era.

\section{B. Differences in the Role of Equity Markets}

The United States since the mid-1990s is also distinctive in another regard: equity markets and their prices have played a larger role in the process by which proposed investment projects are chosen than they have in the other three moments in economic history under examination.

\section{The United States since 1995 versus the United States 1970-1990}

The finance process in the United States went through significant transition starting in the mid-1980s, whereby external equity markets and their prices began to play a larger role.

a. Focus on share value maximization. Compared to earlier time periods, the focus in the United States in recent years has been much more on share value maximization as the primary goal of established, publicly traded corporations. ${ }^{53}$ This change in focus was supported by a number of institutional

\footnotetext{
${ }^{53}$ See Jeffrey N. Gordon, The Rise of Independent Directors in the United States, 1950-2005: Of Shareholder Value and Stock Market Prices, 59 STAN. L. REV. 1466 (2007) (tracing the history of this change in focus to shareholder value). Benght Holmstrom \& Steven N. Kaplan, Corporate Governance and Merger Activity in the United States: Making Sense of the 1980s and 1990s, $15 \mathrm{~J}$. ECON. PERSP. 121 (2001) (documenting a move toward a more market-oriented style of corporate governance in the United States).
} 
changes: a more active market for corporate control, boards that are increasingly independent of operating management, and share-price based compensation.

The stage opened for this change in focus with the sharp increase in the number and size of hostile takeovers in the second half of the 1980s. ${ }^{54}$ Many of these offers involved substantial leverage and many other firms, in an effort to avoid becoming targets themselves, restructured on their own to become more leveraged. ${ }^{55}$ Overall, the result was a payout to the market of a larger portion of established firms' cash flows.

The number of hostile takeover bids subsided by the early 1990s but the surge in the late 1980s left a number of effects in its wake. These effects continued to drive the new focus on share value maximization. One effect was simply to elevate consciousness about the importance of shareholders and the usefulness of measuring their well-being in terms of the share price, an elevated consciousness that seems to have persisted. A second effect of the late 1980s surge was that it proved to all incumbent managers that hostile takeovers can really happen: one quarter of all major firms in the United States were the target of a hostile bid in the $1980 \mathrm{~s} .{ }^{56}$ With this reminder of an always looming threat of takeover, fewer incumbent management teams were likely to deviate substantially from making share value maximizing decisions. The drop in hostile offers in the 1990s thus may actually have been a sign of the power of this threat: there were fewer hostile offers because there may have been less need for them.

A third effect of the hostile takeover surge in late 1980s - a legislative and judicial backlash that permitted incumbent managers to engage in increasingly effective takeover defenses - would, at first glance, appear to have worked in the opposite direction, providing a shield for non-share-value-maximizing managers. But, ironically, the opposite seems to be the case. The availability of these defenses tended to be contingent upon the firm having a more genuinely independent, monitoring board of directors. ${ }^{57}$ The movement toward more independent monitoring boards was spurred as well by the increasing portion of

\footnotetext{
${ }^{54}$ G. William Schwert, Hostility in Takeovers: In the Eyes of the Beholder?, 60 J.FIN. 2599, 2611 (2000). Schwert shows the level of offers labeled as "hostile" to be higher in every year from 1985-1989 than it was in any year before in the survey, which goes back to 1975. The author cautions that offers are often characterized as hostile because the target management is engaging in strategic bargaining to get a better price, rather than just to protect their incumbency. The opposite occurs often, as well, where a board invites, or at least decides not to resist, what is labeled a "friendly" bid in order to gently remove incumbent management. See also John C. Coates, IV \& Reinier Kraakman, CEO Tenure, Performance and Turnover in S\&P 500 Companies, available at http://papers.ssrn.com/sol3/papers.cfm?abstract id=925532

${ }_{55}^{55}$ Holmstrom \& Kaplan, supra note 53, at 124.

${ }^{56}$ Mark L. Mitchel \& J. Harold Mulherin, The Impact of Industry Shocks on Takeover and Restructuring Activity, 41 J. FIN. ECON. 193, 199 (1996).

${ }^{57}$ Gordon, supra note 53, at 1522-23.
} 
Fox: Promoting Innovation: The Law of Publicly Traded Corporations

shares held by corporate-governance-concerned institutional investors. These more independent boards in turn acted in a number of ways that spurred share value maximizing managerial behavior. To start, because of their greater independence and their raised consciousness concerning shareholder welfare, these boards became more effective monitors of share value maximizing behavior on the part of established firm managers. There has been, for example, an increase in the rate of turnover of CEOs and an increased relationship between turnover and share price performance. ${ }^{58}$ Also, these boards were more prone to accept, and even prompt, offers that would result in the replacement of incumbent management where they believed the offered price was superior to the value that incumbent management could deliver. As a result, many apparently friendly offers were really motivated by aboard recognition of the need for control change, ${ }^{59}$ a trend that was further accentuated by lessened incumbent management resistance due to the increasing use of golden parachutes. ${ }^{60}$ Finally, these boards brought in additional market discipline through the steep increase in the use of share-price based compensation. ${ }^{61}$

b. IPOs. IPO figures tend to swing rather sharply from one year to the next and are very sensitive to overall economic conditions. Nevertheless, longer term data concerning initial public offerings also show a break, starting in the second half of the 1980s and solidifying in the 1990s and the first half of the 2000 s, that demonstrates that IP0s have taken on significantly greater importance in the economy, at least until the recent great recession and financial crisis.

In the 1970 s, total proceeds from IPOs per year averaged about $.04 \%$ of U.S. GDP and in no year were greater than $.24 \%$ of GDP. ${ }^{62}$ The number of IPOs

\footnotetext{
${ }^{58}$ Steven N. Kaplan \& Bernadette A. Minton, How Has CEO Turnover Changed? Increasingly Performance Sensitive Boards and Increasingly Uneasy CEOs, NBER Working Paper (2006), available at: http://papers.ssrn.com/sol3/papers.cfm?abstract id=924751 (turnover in the period 1992-2005 period was more rapid than shown in studies of earlier periods and more related to share price performance); Mark R. Huson et al., Internal Monitoring Mechanisms and CEO Turnover: A Long-Term Perspective, 56 J. FIN. 2265, 2295 tbl. VII (2001) (CEO firings were accompanied by a $4.00 \%$ positive market-adjusted share price reaction in the 1989-1994 period, as compared to a $1.75 \%$ positive reaction in the $1983-1988$ period, suggesting that firing decisions were more attuned to market preferences in the latter period).

${ }^{59}$ Coates \& Kraakman, supra note 54.

${ }^{60}$ Gordon, supra note 53, at 1533-34.

${ }^{61}$ Between 1992 and 2000, for the average S\&P 500 firm CEO, the value of his or her stock options at the day of grant, as measured by a Black Scholes type formula, increased from being $27 \%$ of total compensation to $51 \%$ of total compensation. Kevin Murphy, Explaining Executive Compensation: Managerial Power Versus the Perceived Cost of Stock Options, 69 U. CHI. L. REV. 847, 848 fig. 1 (2002).

${ }^{62}$ The IPO proceeds as a percentage of GDP figures in this section are calculated on the basis of figures for the amount of proceeds from IPOs for each year from Jay R. Ritter, Some factoids about the 2009 IPO market. Available at
} 
averaged 154 per year, with the annual number varying from a high of 562 to a low of $9 .^{63}$

In the $1980 \mathrm{~s}$, total proceeds from IPOs per year averaged about $.12 \%$ of U.S. GDP, and in the highest year was $.32 \%$ of GDP. During the decade, the number of IPOs averaged 329 per year, with the annual number varying from a high of 524 to a low of 75 .

In the 1990s, total proceeds from IPOs per year averaged about $.40 \%$ of U.S. GDP, about ten times the 1970s level and more than three times the 1980s level, and in the highest year were .71\% of GDP. During the decade, the number of IPOs averaged 421 per year, with the annual number varying from a high of 688 to a low of 115 .

In the first eight years of the 2000s, total proceeds from IPOs per year also averaged about .30\% of U.S. GDP, somewhat lower than in the 1990s, but almost triple the 1980s and eight times the 1970s. The number of IPOs dropped to an average number of 220.

c. Venture capital. The role of venture capital in the U.S. economy steadily increased in the two decades between 1980 and 2000. The number of venture funds under management in the United States, under a broad definition that would include funds available for financing non-high-tech start up companies, increased from . $2 \%$ to $.3 \%$ of GDP in the first half of the $1980 \mathrm{~s}$ to $.5 \%$ to $.6 \%$ of GDP in the second half of the $1980 \mathrm{~s}$ and first half of the $1990 \mathrm{~s} .{ }^{64}$ It then shot up shot up at a rapid rate during the tech bubble period of the second half of the 1990 s reaching $1.6 \%$ by 1999 . In the period from 2000 to 2007 venture capital funds under management as a percentage of GDP had a high $2.4 \%$ in 2001 and a low of $1.8 \%$ in 2007 with the other years ranging from $2.1 \%$ to $2.3 \%$, ten times the figure in the early years of the 1980s.

Another way of cutting at the role of venture capital in the U.S. economy is the percentage of GDP per year invested in real investment projects by venture capital funds. Because of shifts in both supply and demand, this figure can vary widely from one year to the next, ${ }^{65}$ but again the longer term trend is toward a much larger role for venture investment in the 1990s and 2000s compared to

http://bear.warrington.ufl.edu/ritter/IPOs2009Factoids.pdf. The GDP for each year from GDP for each year from World Bank World Development Indications (also used for all other U.S. GDP ratios in this Part VI, available at http://www.google.com/publicdata?ds=wbwdi\&met=ny_gdp_mktp_cd\&idim=country:JPN\&dl=en\&hl=en\&q=japan+gdp+statistics\#met=ny gdp_mktp_cd\&idim=country:USA.

${ }^{63} I d$. The number of IPOs for each year in this section are from Ritter, supra note 62.

${ }^{64}$ The venture capital under management as a percentage of GDP figures in this section are calculated on the basis of figures for the amount of venture capital under management for each year from National Venture CAPITAL Association, YearbooK 2008 at 1, figure 1.02.

${ }_{65}$ Josh Lerner, Panacea or Mirage? Venture Capital and Innovation (2008) available at http://www2.law.columbia.edu/contracteconomics/conferences/buslawinnovation08.htm. 
Fox: Promoting Innovation: The Law of Publicly Traded Corporations

earlier. The figure for 1980 was $.02 \%$ of GDP and the average for the first half of the 1980 s was $.05 \%$ of GDP. ${ }^{66}$ During the second half of the 1980 s and the first half of the 1990s, venture capital investments averaged about .06\% of GDP. It soared during the tech bubble period, rising from .11\% of GDP in 1996 to $1.06 \%$ in 2000. It then settled back, and, from 2002 to 2007, was relatively steady averaging about .20\% of GDP, four times the level of 1980-1984 and more than three times the level from 1985-1994. In 2007, 85\% of these funds went to firms in high technology industries. ${ }^{67}$

d. Turnover of large firms. Another measure of the role of capital markets in an economy, though indirect, is the rate of turnover of established firms. This is because the extent to which the cash flow generated by firms with less promising investment opportunities becomes available to fund real investment by firms with more promising opportunities depends on the extent to which managers of established firms are under pressure to maximize share value and on the existence of efficient and effective channels to transfer funds outside firm boundaries. The rate of established firm turnover has accelerated considerably in the United States in recent years. Of the firms listed in the Fortune 500 in 1960 , one third had been replaced by 1980 , a turnover rate of about $2 \%$ per year. ${ }^{68}$ It only took four years for one third of the firms listed in the Fortune 500 in 1998 to be replaced, a turnover rate of almost $10 \%$ per year. $^{69}$

e. Measures of share price accuracy. There is likely to be a positive relationship between share price accuracy and the importance of equity markets in an economy. The directions of causation are likely to run both ways. Going one way, unless share prices are relatively good predictors of future cash flows relative to the available alternatives, an economy that depends on equity prices as an important guide of economic activity is not likely to do well and so such reliance is unlikely to persist for very long. Going the other way, if an economy depends on equity prices as an important guide of economic activity, there will be significant market pressure on issuers, and public pressure on government, to assure a relatively high level of corporate transparency, which is impounded in price and leads to greater price accuracy.

One measure of share price accuracy in increasing use is $\mathrm{R}^{2}$, in essence the portion of firm level variation in share returns that can be explained by marketwide factors using the standard market model. $\mathrm{R}^{2}$ appears to be a good inverse proxy for how much fundamental information concerning future shareholder

\footnotetext{
${ }^{66}$ The percentage of GDP that represents real investment funded by venture capital in this section are calculated on the basis of figures for the amount of venture capital investment each year from NATiOnal Venture CAPital AsSOCiation, YearbooK 2008 at 24, fig. 3.10.

${ }^{67}$ National Venture Capital Association, Yearbook 2008 at 11.

${ }^{68}$ Commission of the European Community, Green Paper: Entrepreneurship in Europe at 8 (2003).

${ }^{69} \mathrm{Id}$.
} 
distributions is impounded in price; the lower $\mathrm{R}^{2}$, the more accurate the share price. The theory is that a low $\mathrm{R}^{2}$ is indicative that the firm is the subject of a relatively rich stream of information over time that, as it comes out, moves price around independent of the factors that move the market as a whole, a theory that has considerable empirical support. ${ }^{70}$

The $\mathrm{R}^{2}$ for the average U.S. firm has been declining fairly steadily since the 1930s. Relevant for the comparisons being made here, it was about .20 in 1970 , about .10 in 1980, about .05 in 1990 and about .02 in $1995 .^{71}$

\section{The United States since 1995 versus Japan since 1995 and Europe since} 1995

Now let us compare the United States since 1995 with Japan since 1995 and with continental Europe since 1995 based on the same factors that we used to compare the role of external equity markets and their prices in the United States 1970-1990 with their role in United States since 1995. It becomes clear that equity markets and their prices play a larger role in the United States than in the other two economies.

a. Focus on share value maximization. As discussed above, the catalyst for the much greater focus on share value maximization in the United States was the wave of hostile takeovers in the second half of the 1980s. Continental Europe and Japan have never had a comparable experience. While there have been changes in recent years that have reduced the security of incumbent managers in both these economies, in neither economy has there been a market for corporate control like the control market in the United States that, combined with the changes in U.S. boards since the 1990s, works in a way that poses as effective a threat for European and Japanese non-share-valuemaximizing managers as is faced by such U.S. managers. ${ }^{72}$ Share value

\footnotetext{
${ }^{70}$ The seminal article is Randall Morck et al., The Information Content of Stock Markets: Why do Emerging Markets have Synchronous Stock Price Movements?, 58 J. Fin. ECon. 215 (2000). See Merritt B. Fox, Randall Morck, Bernard Yeung \& Artyom Durnev, Law, Share Price Accuracy, and Economic Performance: The New Evidence, 102 Mich. L. REv. 331, 357-366 (2003) for a more detailed discussion of the theory and a review of the confirmatory empirical studies.

${ }^{71}$ Morck et al., supra note 70 at 222, figure 3, 223, table 2.

${ }^{72}$ See, e.g., Jeffrey N. Gordon, An American Perspective on the New German Anti-Takeover Law, Die Aktiengesellschaft, vol. 12, at 4 (Dec. 2002), available at http://ssrn.com/abstract=336420; Curtis J. Milhaupt \& Mark D. West, Institutional Change and M\&A in Japan: Diversity Through Deals, in Global Markets, DOMESTIC InSTITUTIONS: CORPORATE LAW AND GOVERNANCE IN A New Era of Cross-Border DeAls (Curtis J. Milhaupt, ed. 2001); Curtis J. Milhaupt, A Lost Decade for Japanese Corporate Governance Reform: What's Changed, What Hasn't, and Why, Columbia Law School Center for Law and Economic Studies Working Paper (2003); Curtis J. Milhaupt, In the Shadow of Delaware: The Rise of Hostile Takeovers in Japan, 105 Colum. L. REV. 2171 (2005).
}

DOI: $10.2202 / 1932-0213.1078$ 
Fox: Promoting Innovation: The Law of Publicly Traded Corporations

maximization is not the clearly stated goal of the board and other participants in corporate governance in firms in continental Europe and Japan. ${ }^{73}$ There is also considerably less use of share price-based executive compensation. ${ }^{74}$

b. Level of IPOs. IPOs were almost unheard of in Japan in the 1970s and 1980s but became an established form of financing starting in the 1990s. Still, relative to the United States, they play a smaller role in the economy. From 2000through 2007, proceeds from IPOs represented a yearly average of about $.2 \%$ of GDP in Japan ${ }^{75}$ compared to about $.3 \%$ in the United States. The continental European countries tell a different story. For those eight years, proceeds from IPOs as a percentage of GDP represented a yearly average for France, Germany and Italy, respectively, of .68\%, .61\% and $.57 \%$. These figures, however, are greatly inflated by the first three years of the decade, where there appear to have been some very large, established private corporations that went public. The respective figures for the five years $2003-2007$ are $.30 \%, .18 \%$ and $.39 \%$.

c. Venture capital. Comparing the importance of high tech venture capital in different economies is tricky because of differences in definitions and institutions. A rough picture emerges, however.

In the Eurozone, total private equity invested as a percentage of GDP for the six years running from 2002 to 2007 inclusive averaged about .12\% per

\footnotetext{
${ }^{73}$ See Reinier KraAkman et al., The Anatomy of Corporate Law (2009 2d ed.) for a comprehensive discussion of the similarities and differences among these different systems in solving the basic problems of governing large businesses organized in the corporate form. See also citations in note 72 supra and note infra.

${ }^{74}$ Gordon, supra note 72 . The importance of outside finance for project choice in an economy has been recognized for a long time, and has continued to be a focus of research. See, e.g. JOSHPH A. SCHUMPTER, THeOry of ECONOMic DeVelopment (1911); JohH R. Hicks, A TheORY of ECONOMIC HISTORY 143-145 (1969) (emphasizing the liquidity provided by financial markets as critical to early industrial development in England, France and Holland); Raghuram G. Rajan \& Luigi Zingales, Financial Dependence and Growth, 88 AM. ECON. REv.. 559 (1998) (cross country study showing relationship between financial market development and rate of growth of firms relying on external finance and relationship of such development and flourishing of smaller high technology firms); Ross Levine, Finance and Growth: Theory and Evidence, in HANDBOOK OF ECONOMIC Growth (2005). For a skeptical view, see JOAN RoBInSON, THE RATE OF INTEREST AND OTHER ESSAYS (1952) (finance follows industry).

${ }^{75}$ The IPO proceeds as a percentage of GDP figures in this section for Japan, France, Germany and Italy are calculated on the basis of figures for the amount of proceeds from IPOs for each year from Thompson Financial Securities Data and the GDP for each year from World Bank World Development Indications, available at http://www.google.com/publicdata?ds=wbwdi\&met=ny_gdp_mktp_cd\&idim=country:JPN\&dl=en\&hl=en\&q=japan+gdp+statistics.
} 
year. $^{76}$ Private equity, however, includes buyouts and equity financing for established private companies. About $30 \%$ of private equity appears to be for seed, start-up and expansion purposes, what in the United States would be considered venture capital. ${ }^{77}$ Thus, about .04\% of GDP during these years went to venture investments in continental Europe, compared to $.20 \%$ for the United States, about five times as much. The same basic story is told by figures from other sources, using perhaps somewhat different definitions, for the period 20002003. These figures suggest that venture capital investments for venture capital were $.10 \%, .09 \%$ and $.08 \%$ of GDP for France, Germany and Italy respectively. ${ }^{78}$ This compares to a figure from the same source of $.38 \%$ for the United States, about four times as great. Moreover, about $75 \%$ of the U.S. venture capital investment during this period went to firms in high technology sectors, whereas only $35-40 \%$ did in France, Germany and Italy. ${ }^{79}$

Venture capital investment in high technology firms is even less important in the Japanese economy. For the period 2000-2003, it was about $.02 \%$ of GDP, with the U.S. figure for the period being $.40 \%$, about twenty times as great. ${ }^{80}$ Moreover, only about $35 \%$ of the Japanese venture capital investment that did occur during this period went to firms in high technology sectors, compared again to the U.S. figure of $75 \%{ }^{81}$

d. Turnover of large firms. The turnover rate in the United States is considerably higher than in Europe. Eight of the 25 largest firms in the United States in 2003 did not exist or were very small in 1960. All of the largest firms in Europe in 1998 were already large in $1960 .^{82}$

e. Share price accuracy. As discussed above, $\mathrm{R}^{2}$, the portion of firm level variation in share returns that can be explained by market-wide factors

\footnotetext{
${ }^{76}$ This figure is calculated on the basis of figures for European Private Equity Capital Investments by Year in National Venture Capital Association Yearbook 2008 (prepared by Thompson) at 98, figure 14. The Eurozone GDP figures come from Eurostat Yearbook 2010 at 98, Table 1.2.

${ }_{78}^{71}$. at 99 , figure 16 .

${ }^{78}$ OECD Science, TeChNology And Industry SCOREboARD 2005, 43. Data from yet another source for the period 1999-2002 suggests approximately the same difference in the importance of venture investments between the major continental European economies and the United States. These figures show that venture capital investment in high-technology sectors as a percentage of GDP are $.12 \%, .08 \%$ and $.06 \%$ for France, Germany and Italy respectively, with the comparable figure for the United States being $.40 \%$. OECD, VENTURE CAPITAL: TRENDS AND POLICY RECOMMENDATIONS 9, Figure 2 (2003).

${ }^{79}$ OECD SCIENCE, TECHNOLOGY AND INDUSTRY SCOREBOARD 2005, 42-43.

${ }^{80}$ OECD SCIEnCE, TeChnOlogy and Industry SCOREBOARD 2005, 43. The figures for 19992002 are comparable. OECD, Venture Capital: Trends and Policy Recommendations 9, Figure 2 (2003).

${ }^{81}$ OECD SCIENCE, TECHNOLOGY AND INDUSTRY SCOREBOARD 2005, at 43.

${ }^{82}$ Commission of the European Community, Green Paper: Entrepreneurship in Europe at 8 (2003).
} 
Fox: Promoting Innovation: The Law of Publicly Traded Corporations

using the standard market model, appears to be a good inverse proxy for how much fundamental information concerning future shareholder distributions is impounded in price. The $\mathrm{R}^{2}$ for the average French firm in 1995 was .075 , in Germany, .114, in Italy, .183, and in Japan, .234. ${ }^{83}$ These figures compare with .021 in the United States, suggesting that U.S. share prices were significantly more accurate. ${ }^{84}$

\section{Conclusions}

The data discussed above clearly shows that the United States has enjoyed a significantly greater increase in innovation induced productivity than have the economies in the other three moments of economic history under examination. In combination, the data discussed above, when considered as a whole, also tells a convincing story that equity markets and their prices have played a larger role in the process by which investment projects are chosen in the United States since 1995 than in the United States between 1970 and 1990. The same can be said for the comparison of the United States since 1995 and continental Europe and Japan since 1995. This data provides strong support for the statement of Baumol, Litan and Schram: "Only in the United States, at least so far, is [the] task of transmission of financial resources from savers to producers carried on primarily in organized markets, such as stock and bond markets, rather than by banks. ${ }^{, 85}$

Is there a connection between this larger role for equity markets and their prices and the greater innovation induced rate of productivity gains that have been observed in the United States since 1995? This is of course much harder to prove. Many other things change over time and many other differences exist between economies that can contribute to differences in the rate of productivity gains. Such other factors include the regulation and structure of labor markets, taxes, the size of a market in which there are truly no restrictions on the movement of goods, services and factors of production, and even possibly societal attitudes toward risk. Nevertheless, the results of this exercise in crude empiricism are completely consistent with the theoretical story told in this paper.

\footnotetext{
${ }^{83}$ Morck et al., supra note 70 , at 222, figure 3, 223, table 2.

${ }^{84}$ Id.

85 William J. Baumol, Robert E. Litan, \& Carl Schramm, Good Capitalism, Bad CAPITALISM, AND THE ECONOMICS OF GROWTH AND PROSPERITY (2007).
} 


\section{CORPORATE AND SECURITIES LAW}

We live in an era in which the rate of scientific discovery creates the potential for rapid improvements in productivity through technical change. This potential is more likely to be realized, I have argued, in an economy with three key characteristics: deep, vibrant equity markets, the practical availability of the dispersed pattern of shareholdings as a form of corporate ownership for entrepreneurs who deem this pattern of ownership to be desirable, and managers of established firms who are deterred from over-retaining cash flow and who are otherwise challenged to find good projects and maximize share value.

\section{A. Looking at the "Market Centered" versus "Bank Centered" Corporate Governance Debate in a New Light}

While the terms "market centered" and "bank centered" systems of corporate governance oversimplify the range of corporate finance and governance systems available to an economy and the ways these systems can differ, forcing, as they do, any given economy into one of just two categories, the ideal argued for here clearly falls into the general "market centered" category. There continues to be an intense debate over which of these two general categories of systems is the more desirable, with commentators often dividing along national lines. This paper does not attempt to resolve the debate as it has been traditionally conducted, where the arguing points for each side, properly categorized, relate largely to static economic efficiency. ${ }^{86}$ This paper argues that the system of corporate finance and

\footnotetext{
${ }^{86}$ For a discussion of the relationship between strong securities markets and economic growth, see Ross Levine, Financial Development and Economic Growth: Views and Agenda, 35 J. ECON. LIT. 688 (1997)(collecting studies); Bernard S. Black, The Legal and Institutional Preconditions for Strong Securities Markets, 48 UCLA L. REV. 781, 832-34, 835-38 (2001) (same). For empirical evidence that the direction of causation leads from financial development generally (both in the form of a banking sector and of stock markets) to economic growth and not the other way around, see Raghuram G. Rajan and Luigi Zingales, Financial Dependence and Growth, 88 AM. ECON. REV. 559-86 (1998). For further discussion of the advantages of dispersed ownership, see Erik Berglof \& Stijn Claessens, Corporate Governance and Enforcement 3, 12, 47, http://papers.ssrn.com/sol3/papers.cfm?abstract_id=625286.

A number of static efficiency arguments in favor of deep, vibrant equity markets and dispersed ownership are suggested by this literature. By making it easier for issuers to raise funds and investors to invest, economies with these features facilitate the transfer of funds from stable or declining firms, which have substantial cash flows but few promising new investment projects, to growing, often new, firms, which have less cash flow but many promising investment projects. By making diversification easier, dispersed ownership promotes the more efficient allocation of risk. The liquidity that deep, vibrant markets provide both lowers the cost of capital for issuers and increases investor utility. Share prices in such markets also more efficiently impound information held by diverse persons that is relevant to predicting an issuer's future cash flows and in so doing help managers to make decisions based on more accurate cash flow projections. Management can
} 
Fox: Promoting Innovation: The Law of Publicly Traded Corporations

governance advocated here has the different, less appreciated virtue of better promoting dynamic efficiency. The resulting welfare gains are likely to swamp the advantages of whichever side of the debate is right in terms of static efficiency.

\section{B. Promoting Vibrant, Deep Equity Markets and Making Dispersed Ownership Practically Available}

Because the "market centered" system already has its many adherents based on their perceptions of its static efficiency advantages, considerable attention has been paid to the legal arrangements that promote its development. To start, vibrant, deep equity markets and dispersed ownership structures appear to be impossible without a high level of corporate transparency. ${ }^{87}$ This disclosure will

be disciplined in such a system by low barriers to hostile takeover and a high level of transparency.

One argument in favor of a "bank centered" system, and for less concern with facilitating dispersed shareholding, is that the bank or the dominant shareholder is a much more effective monitor of the manager than is possible is a dispersed system. John C. Coffee, Jr., The Rise of Dispersed Ownership: The Roles of Law and State in the Separation of Ownership and Control, 111 YALE L..J. 1, 16-17 (2001). Another argument in favor of the bank-centered system arises out of a disagreement that share value maximization is socially desirable. This disagreement represents skepticism that the prices of a firm's inputs and outputs are sufficiently close to their social costs and benefits that the firm's cash flow is a reasonable measure of its contribution to society. This skepticism, combined with a belief that management can be motivated, if freed of the need to maximize share value, to make decisions that better reflect the true social costs and benefits of the firm's activities. Adherents of a bank centered model believe that in such a system managers can be freed of the need to maximize share value and motivated to take account of the true social costs and benefits their firms' activities. Michael Gruson \& Wienand Meilicke, The New Co-Determination Law in Germany, 32 Bus. Law. 571 (1977); Detlev F.Vagts, Reforming the "Modern" Corporation: Perspectives from the German, 80 HARV. L. REV. 23, 38- 43 (1966).

${ }^{87}$ Black, supra note 86, at 783, 834-35 (collecting empirical studies showing relationship between transparency and depth of equity markets measured by indicators such as the ratio of stock market capitalization to GDP); Frank B. Cross \& Robert A. Prentice, The Economic Value of Securities Regulation, 28 CARDozo L REv. 333, 376-87 (same); Hazem Daouk et al., Capital Market Governance: How Do Security Laws Affect Market Performance 25, $\mathrm{http}: / /$ papers.ssrn.com/sol3/papers.cfm?abstract id=702682 (study linking transparency to cost of capital and liquidity); Eirk Berglof \& A. Pajuste, Corporate Governance in Central and Eastern Europe, in Global Competitiveness And Corporate Governance (P. Cornelius \& B. Kogut eds., 2003) (how countries markets in transition countries with poor transparency were quickly transformed, after initial privatization auctions created dispersed ownership, to concentrated ownership economies); JoHn C. COFFEe, JR., GATEKEEPERs: THE PROFEsSions AND CoRPORATE GOVERNANCE 109 (2006) (dispersed ownership and the separation of ownership from control not possible without reliable, audited financial statements), John C. Coffee, Privatization and Corporate Governance: The Lessons from Securities Market Failure, in CORPORATE GOVERNANCE LESSONS FROM TRANSITION ECONOMY REFORMS 274-281(M. Fox \& M. Heller eds, 2006) (comparing the disappearance of market trading for most of the nearly 1500 Czech issuers 
be under-produced without a system of mandatory disclosure rules, because issuer disclosure's social costs are less than the private costs to the issuer and its social benefits are greater than the private benefits to the issuer. ${ }^{88}$ Such rules are not meaningful unless they are effectively and fairly enforced by governmental authorities and/or private litigation. ${ }^{89}$

Vibrant, deep equity markets and dispersed ownership structures are also not possible without some kind of restraint on management and powerful shareholders that prevents them from directing to themselves non-pro-rata division corporate cash flows or assets. Such a restraint is a fundamental feature of good corporate governance. ${ }^{90}$ It is needed because concerns about such nonpro-rata divisions make potential non-controlling investors unwilling to pay a sufficiently high price for newly offered shares to make the offering worthwhile for the issuer. ${ }^{91}$ This restraint will come from corporate law rules prohibiting such non-pro-rata divisions, again effectively enforced by public authorities or private litigation. Because enforcement requires awareness, corporate transparency is a precondition for such effective enforcement. ${ }^{92}$

created by the privatization in the early 1990s with the better performance of the Polish capital markets and attributing the difference in part to very poor issuer disclosure in the Czech Republic with relatively high quality issuer disclosure in Poland).

${ }^{88}$ The disadvantages to an issuer from its competitors, major suppliers and major customers obtaining from the issuer's disclosures information that helps them compete or deal more effectively with the issuer are private costs to the issuer, but not costs to society since the other parties enjoy commensurate gains. As for the divergence of social and private benefits, one issuer's disclosure helps the market better predict the future cash flows of other issuers, which produces social benefits in terms of reducing the agency costs of management of these other firms and improving the allocation of capital. These social benefits cannot be captured by the disclosing firm and thus are not private benefits. Merritt B. Fox, Retaining Mandatory Disclosure: Why Issuer Choice is Not Investor Empowerment, 85 VA L. REV. 1335 (1999).

${ }^{89}$ John C. Coffee, Jr., Law and the Market: The Impact of Enforcement, 156 U. PENN. L. Rev. 229 (2007); Rafael La Porta, Florencio Lopez-De-Silanes \& Andrei Shleifer, What Works In Securities Laws? 61 J. FIN. 1 (2006) (empirical study finding a relationship between the availability of private enforcement of securities laws and capital market development), Merritt B. Fox, Why Civil Liability for Disclosure Violations When Issuers Do Not Trade, 2009 WISC. L. REV. 297 (deterrence rationales for civil damage actions).

${ }^{90}$ Merritt B. Fox \& Michael A. Heller, Corporate Governance Lessons from Russian Enterprise Fiascoes, 75 NYU L. REV. 1720, 1723-27, 1740-45, 1770-71 (2000).

${ }^{91} I d$. at 1725 .

${ }^{92}$ See, e.g., OECD Principles of Corporate Governance (2004); Mark J. Roe, Corporate Law's Limits, 31 J. LEGAL STUD. 233 (2002) (corporate law is ineffective without transparency). While transparency is a precondition for effective enforcement of corporate law rules against such nonpro-rata divisions, it might be sufficient by itself if combined with the absence of majority shareholder and low barriers to a hostile takeover. 
Fox: Promoting Innovation: The Law of Publicly Traded Corporations

\section{Preventing Over-retention of Internal Funds by Established Firms}

Finally, disciplining management of established firms in a dispersed shareholder system depends on a securities and corporate law that poses low barriers to hostile takeover and that permits appropriately designed share-price based compensation. Again, the increased transparency that comes from effective mandatory disclosure assists in the operation of both these devices to prevent managers from overretaining earnings and to encourage them more generally to maximize share value. $^{93}$

\section{CONCLUSION}

The pivotal role of innovation in increasing productivity is well established. Most innovation requires new real investment. A high rate of improvement in economic welfare therefore requires that the process in an economy that allocates society's scarce savings among proposed real investment projects be sensitive to the prospects promising new innovation. This Article's ultimate goal is to begin to consider how corporate and securities law, which help structure important elements of this process, can be designed to promote such sensitivity.

In service of this ultimate goal, the article sketches out an unconventional approach to thinking about the functioning of this process in a market economy. This approach is based on a seemingly paradoxical analogy of the finance process to the way a hierarchical organization, when making decisions, gathers and processes relevant bits of information dispersed among many individuals. Using this analogy, the approach takes advantage of important thinking in communications and organizational theory about how organizations can be structured to be sensitive to the potentialities of new information and ideas.

The core of the analogy of a market economy's finance process to a hierarchical organization is the observation that ultimate decision makers in the process - savers - lack most of the disparately held information needed to assess and compare each proposed investment project in the economy and that they solve this problem by a combination of advice seeking and decision delegation. The usual view is that markets and hierarchical organizations are sharply distinct substitutes for each other. This usual view arises from a focus on the allocation of resources for current production and consumption. Here, as Hayek so persuasively argued, using the market enormously lowers the cost of information handling. Each consumer needs only to look inside herself to her prior experience with the goods she consumes and to her utility function, and each producer to its production function. Prices incorporate all the rest of the information needed to

${ }_{93}$ Merritt B. Fox, Civil Liability and Mandatory Disclosure, 109 Colum. L. REv. 237, 258-59 (2009). 
coordinate their actions into a societal decision as to what quantities of each good to produce, what combination of inputs to use in producing each, to whom the output of each good is allocated.

In contrast, an investment opportunity - the potential for transforming resources today into goods for consumption tomorrow based on a given idea - is perfectly elastic in supply and is thus not competitively priced. The cost of the investment is the cost of the real resources needed to implement it. Individual savers need to look outside themselves for information on the idea's prospects. They thus bear some resemblance to heads of hierarchical organizations. They seek advice and use decision delegation to deal with their information deficiencies, but, by their choices concerning from whom to seek advice and to whom to delegate, their decisions determine the structure of the whole system.

If we judge the finance process as an organization seeking to make decisions allocating society's scarce savings to the most promising investment project proposals, we can use three criteria. Is the system's best evaluation of a proposal's prospects being heeded? Is information concerning each proposal being sent to the persons most capable of evaluating its prospects? And is the system achieving these first two goals in a cost effective fashion in terms of the real resources the system itself consumes.

With these criteria in mind, consider two possible market economy finance systems. The first system is relatively closed. Project implementation is dominated by established firms using either internal funds or funds from banks with which the firms have strong, established relationships. The managers of these established firms are largely protected from removal by a vote of disinterested directors or of dissatisfied shareholders or by a hostile takeover. The second system is more open. A larger share of project implementation is undertaken by relatively new firms. Established firms pay out a greater portion of their cash flow and for external finance rely more on capital markets and less on banks with which they have established relationships. The incumbent managers of the established firms in this more open economy are more vulnerable to removal in reaction to a poor performance, evaluated in part by the medium term share price performance of their firms.

The closed system is ideal in a world of slow change, where the rate of scientific discovery translatable into new products and processes is low. First, the system is likely to implement the projects that its best evaluations suggest have the best prospects. New project proposals in a world of slow change will not be very different from the projects that have already been implemented. They will typically involve the replacement of, or an addition to, a similar project already existing in the economy. The proposal for such a project is most likely to come from an employee of the firm operating the existing project. A firm that operates in a market with a gradually increasing demand or which has a superior record of 
Fox: Promoting Innovation: The Law of Publicly Traded Corporations

figuring out minor product or process improvements will have a list of projects which are superior to those of a firm with the opposite characteristics. It will also be more profitable. Thus the most funds automatically go to the evaluators who are being presented the most promising projects to evaluate. Second, the information concerning each proposal is likely to be sent to the persons in the economy most capable of evaluating its prospects. In a closed system, the information relevant to evaluating the prospects of a proposed project goes to only a few people: the top managers of the firm for which the proponent is an employee or the bankers with which the firm has a close relationship. These are the people best able to use this information, however. Because of their familiarity with the firms' existing projects and the economic environment within which these projects operate, they will have an inherent advantage over outsiders in evaluating the similar project that is being proposed. Finally, the system achieves these first two goals in a cost effective fashion because an information and decision system uses less real resources when it relies primarily on communication among persons who are already familiar with each other and with the situation being appraised.

The closed system is not ideal in a world of fast change, where the rate of scientific discovery translatable into new products and processes is high, as would appear to be the case currently. The system is not likely consistently to implement the projects that its best evaluations suggest have the best prospects because proponents of the most promising projects are not necessarily employees of the firms with the most internal cash flows. And the information concerning each proposal is often not sent to the persons in the economy most capable of evaluating its prospects because the top managers of a proponent's employer may not be the persons most capable of judging the project's potential. In essence, the low operating costs of a closed system are likely to be a false economy.

The analogy of the finance process to a hierarchical organization is useful in understanding what is going on here. An organization is sensitive to new ideas useful for making better decisions when it has the ability to rearrange items of information in new patterns and identify the occasions when a particular rearrangement would be useful. For the system to be able to allow new ideas through, the symbols must aggregate less information. Multiple evaluators are needed because people vary in what they would be sensitive to. People making decisions should not be narrow experts. There should not be too much autonomy in the sense of decisions being chopped up with each participant having a clearly defined zone of authority with respect to her little part, because people learn from each other in collaborative decision-making. Some uncertainty in the environment is good: stress leads to the questioning of old truths. All of this requires more real resources: there is a tradeoff between a system's cost of information handling and its sensitivity to useful new ideas. 
This analysis suggests something about what the structure of a finance process most sensitive to promising innovative new investment project proposals would look like. The incumbent managers of established firms should be under some threat of replacement, judged in part, at least in the medium run, by the share price performance of their firms. Established firms should pay out a relatively high portion of their cash flows back out into the market. There should be a substantial venture capital sector and an active market for IPOs. For the equity markets to play the role contemplated here properly, primary and secondary market prices should be relatively accurate, which requires, among other things, a high level of issuer transparency.

This story tends to be supported by the crude empiricism presented here with respect to the four moments in economic history: the United States in the 1970s and 1980s, Japan since 1995, continental Europe since the 1995, and the United States since 1995. The United States since 1995, relative to the other three moments in economic history, has had the least capital deepening and the fastest rate of growth in productivity per hour worked. It has also had, relative to the other three moments, a finance system most closely resembling what is called for here.

Reaching the best point in the tradeoff between sensitivity to promising innovative investment project proposals and the cost of system operation is not automatic. Specifically, and most important to the discussion here, the legal system is one of the factors that determines a particular economy's point on this tradeoff. In addition, there is probably some path dependency in the sense that an economy's historical experience tends to be self reinforcing, whereby each part of the system is most rewarded when its behavior fits with the other parts of the system. Also, while the supply of innovative project proposals has been treated so far as exogenous, undoubtedly potential proponents are more likely to focus on generating such ideas and to bring what they generate forward if there is a better chance that their proposals will be implemented. Thus a more sensitive overall system will prompt a bigger flow of promising innovative investment project proposals.

The finance system structure that I suggest is most conducive to innovation sounds very much like the "market centered" system as it is somewhat caricatured in the "market centered" verus "bank centered" debate about corporate governance over the last few decades. Much of this debate, though, has been about which system can generate a higher level of static efficiency - the optimal allocation of resources holding technology constant - plus, for some adherents of one side or the other, the implications of the choice for other values such as self realization through work by providing a place for self management, craft, professionalism or creativity, just distribution, and a sense of community and democratic participation among the employees of a firm. Though not totally 
unconnected to these various concerns, the focus here is on what kind of system can achieve dynamic efficiency, with its potential over time for much greater welfare gains than can be achieved by static efficiency.

The market versus bank centered corporate governance debate is useful to our task here, however, because it has prompted considerable thought about the necessary legal preconditions for a market centered system to develop and succeed. These include effectively enforced securities disclosure and anti-fraud laws to promote issuer transparency. Transparency leads to securities market liquidity and a lower cost of capital, which are needed for IPO markets to flourish and for capital markets to transfer savings effectively from established firms with a surplus of internal funds relative to their supply of good investment ideas to ones with a deficit of internal funds relative to such ideas. Issuer transparency also leads to greater share price accuracy, which in turn assists mechanisms such as the market for corporate control and share-price based compensation to limit managerial agency costs, in particular the managerial tendency to invest in negative NPV projects to maximize firm growth when a firm has a surplus of cash flow relative to its number of good investment ideas. In addition, corporate law must not provide incumbent management the means for too much protection against removal by hostile tender offer or shareholder or independent board vote, and it should make share-price based compensation legally practical. Finally, corporate law needs to assure investors that it provides serious constraints on nonpro-rata distribution among shareholders of the wealth created by the firm, because otherwise firms wishing to do IPOs will not be able to sell them at a price worth their issuance.

Relating the law of publicly traded corporations to the promotion of innovation is a large project. The idea that a finance process of the type recommended can help innovation and that law plays a role is not an entirely new idea, but it has not been thought through very systematically. This article is a first step that sketches out the broad outline of a promising approach. The key message is that in the academic and policy discussions of corporate and securities law, much more attention must be paid to their effect on innovation. This can only be ascertained by looking at their effect on the operation of finance process as a whole. 
Capitalism and Society, Vol. 5 [2010], Iss. 3, Art. 1

\section{References}

Acs, Zoltan J. \& David B. Audretsch (1990), Innovation and Small Firms Cambridge, Mass., MIT Press.

Aghion, Philipe \& Peter Howitt (1998), Endogenous Growth Theory, Cambridge, Mass., MIT Press.

Arrow, Kenneth (1975), "Vertical Integration and Communication," Bell Journal of Economics, 6, 173-183.

— (1974), The Limits of Organization, New York, New York, W.W. Norton.

Arrow, Kenneth (1962), "Economic Welfare and the Allocation of Resources for Invention," Nelson, Richard R. ed., in The Rate and Direction of Inventive Activity, Charlotte, N.C.; UMI Publications.

Atanassov, Julian, Vikram Nanda \& Amit Seru (2007), "Finance and Innovation: The Case of Publicly Traded Firms," http://ssrn.com/abstract $=740045$.

Baccara, Mariagiovanna \& Ronny Razin (2009), "Innovation and Corporate Conservatism;" http://papers.ssrn.com/sol3/papers.cfm?abstract id=1434458.

Baker, George P., Michael C. Jensen, and Kevin J. Murphy (1988), "Compensation and Incentives: Practice vs. Theory," Journal of Finance, 43, 593-616.

Bator, Fancis M. (1957), "The Simple Analytics of Welfare Maximization," American Economic Review, 47, 22-59.

Baumol, William J., Robert E. Litan, \& Carl Schramm (2007), Good Capitalism, Bad Capitalism, and the Economics of Growth and Prosperity, New Haven, Yale University Press.

Baumol, William J. et al. (1970), "Earnings Retention, New Capital and the Growth of the Firm," Review of Economics and Statistics, 52, 345-355. 
Fox: Promoting Innovation: The Law of Publicly Traded Corporations

Becker, Ralf and Thomas Hellmann (2003), The Genesis of Venture Capital Lessons from the German Experience, Munich, University Center for Economic Studies.

Berglof, Erik \& Anete Pajuste (2003), "Corporate Governance in Central and Eastern Europe," Cornelius, P. \& B. Kogut eds., Global Competitiveness and Corporate Governance, New York, Oxford University Press.

Berglof, Erik \& Stijn Claessens (2004), "Enforcement and Corporate Governance," http://papers.ssrn.com/sol3/papers.cfm?abstract id=625286.

Bhidé, Amar (1994), "How Entrepreneurs Craft Strategies that Work" Harvard Business Review, 72, 157-188.

Black, Bernard S. (2001), "The Legal and Institutional Preconditions for Strong Securities Markets," UCLA Law Review, 48, 781-855.

Black, Bernard S. \& Ronald J. Gilson (1996), "Venture Capital and the Strucutre of Capital Markets: Banks versus Stock Market," Journal of Financial Economics, 47, 243-277.

Block, Z. (1982), "Can Corporate venturing Succeed?," Journal of Business Strategy, 3, 21-33.

Bright, James Rieser (1964), Research, Development, and Technological Innovation Homewood, Ill., R.D. Irwin.

Bronwyn H. Hall, Bronwyn H. (2002), "The Financing of Research and Development," Oxford Review of Economic Policy, 18, 35-51.

Brown, James, Steven Fazzari \& Bruce Petersen (2009), "Financing Innovation and Growth: Cash Flow, External Equity, and the 1990s R\&D Boom," Journal of Finance 64, 151-185.

Bums, T. and G. Stalker (1961), The Management of Innovation, London, Tavistock Publications.

Chandler, Alfred D. (1962), Strategy and Structure, Cambridge, M.I.T. Press.

Carter, Charles F. and B. R. Williams (1958), Investment in Innovation, London, New York, Oxford University Press. 
Christensen, Clayton, M. (1997), The Innovator's Dilemma, Boston, Mass., Harvard Business School.

Coates, IV, John C. \& Reinier Kraakman, CEO Tenure, Performance and Turnover in $S \& P 500$ Companies, Available at http://papers.ssrn.com/sol3/papers.cfm?abstract id=925532.

Coase, Ronald (1937), “The Nature of the Firm,” Economica, 4, 386-405.

Coffee, Jr., John C. (2007) "Law and the Market: The Impact of Enforcement," University of Pennsylvania Law Review, 156, 229-311.

- (2006), Gatekeepers: The Professions and Corporate Governance, New York, Oxford University Press.

(2006), "Privatization and Corporate Governance: The Lessons from Securities Market Failure," in Corporate Governance Lessons from Transition Economy Reforms, Fox, Merritt B. And Michael Heller, eds., Princeton, Princeton University Press.

_ (2001), "The Rise of Dispersed Ownership: The Roles of Law and State in the Separation of Ownership and Control," Yale Law Journal, 111, 1-82.

Commission of the European Community, Green Paper: Entrepreneurship in Europe (2003)

http://eurex.europa.eu/LexUriServ/LexUriServ.do?uri=COM:2003:0027:F IN:EN:PDF.

Commons, John (1934), Industrial Economics, New York, MacMillan.

Cross, Frank B. \& Robert A. Prentice (2006), "The Economic Value of Securities Regulation," Cardozo Law Review, 28, 333-389.

Daouk, Hazem, et al., Capital Market Governance: How Do Security Laws Affect Market Performance 25, http://papers.ssrn.com/sol3/papers.cfm?abstract id=702682

Denison, Edward F. (1967), "Why Growth Rates Differ," The Economic Journal, $79,261-268$. 
Fox: Promoting Innovation: The Law of Publicly Traded Corporations

Deutsch, Karl (1963), Nerves of Government: Models of Political Commentary and Control, London, Free Press of Glencoe.

Donaldson, Gordon (1961), Corporate Debt Capacity; A Study of Corporate Debt Policy and Determination, Boston, Division of Research, Graduate School of Business Administration, Harvard University.

Downs, Anthony (1967), Inside Bureaucracy, Boston, Little, Brown.

Easterbrook, Frank (1984), "Two Agency-Cost Explanations of Dividends," The American Economic Review, 74, 650-659.

Easterly, William \& Ross Levine (2001), "It's Not Factor Accumulation: Stylized Facts and Growth Models, The World Bank Economics Review, 15, 177220.

European Private Equity Capital Investments by Year in National Venture Capital Association Yearbook 2008, prepared by Thompson, http://www.nvca.org/index.php?option=com docman\&task=doc downloa $\underline{\mathrm{d} \& \text { gid }=360 \& \text { Itemid }=464}$.

Eurostat Yearbook 2010, http://epp.eurostat.ec.europa.eu/portal/page/portal/publications/eurostat ye arbook 2010.

Fast, N. (1979), "A Visit to the New Venture Graveyard," Research Management $22,18-22$.

Fogel, Kathy, et al. (2006), Big Business Stability and Economic Growth: Is What's Good for General Motors What's Good for America, Available at http://ssrn.com/abstract $=916547$.

Fox, Merritt B. (2009), "Civil Liability and Mandatory Disclosure," Columbia Law Review 109, 237-308.

_ (2009), "Why Civil Liability for Disclosure Violations When Issuers Do Not Trade," Wisconsin Law Review, 2009, 297-332.

(1999), "Retaining Mandatory Disclosure: Why Issuer Choice is Not Investor Empowerment," Virginia Law Review, 85, 1335-1419. 
(1999), "Required Disclosure and Corporate Governance," Law and Contemporary Problems, 62, 113-127.

— (1997), "Securities Disclosure in a Globalizing Market: Who Should Regulate Whom," 95 Michigan Law Review, 95, 2498-2632.

- (1987), Finance and Industrial Performance, in a Dynamic Economy: Theory, Practice, and Policy, New York, New York, Columbia University Press.

Fox, Merritt B., Randall Morck, Bernard Yeung \& Artyom Durnev (2003), "Law, Share Price Accuracy, and Economic Performance: The New Evidence," Michigan Law Review, 102, 331-386.

Fox, Merritt B. Fox \& Michael A. Heller (2000), "Corporate Governance Lessons from Russian Enterprise Fiascoes," New York University Law Review, 75, 1720-1780.

Gabaix, Javier \& Augustin Landier (2008), "Why Has CEO Pay Increased So Much?," The Quarterly Journal of Economics, 123, 49-100.

Gilson, Ronald J. (2003), "Engineering a Venture Capital Market: Lessons from the American Experience," Stanford Law Review, 55, 1067-1103.

Gilson, Ronald Gilson \& Joseph Bankman (1999), "Why Start-ups?” Stanford Law Review, 51, 289-308.

Gompers, Paul \& Josh Lerner (1996), "The Use of Covenants: An Empirical Analysis of Venture Partnership Agreements," Journal of Law and Economics, 39, 463-498.

Gordon, Jeffrey N. (2007), "The Rise of Independent Directors in the United States, 1950-2005: Of Shareholder Value and Stock Market Prices," Stanford Law Review, 59, 1466-1568.

— (2002), "An American Perspective on the New German Anti-Takeover Law," Die Aktiengesellschaft, 12, 4, Available at http://ssrn.com/abstract=336420;

Gordon, Robert Aaron, (1945), Business Leadership in the Large Corporation, Washington, D.C., The Brookings Institute. 
Fox: Promoting Innovation: The Law of Publicly Traded Corporations

Grabowski, Henry \& Dennis Mueller (1975), "Life Cycle Effects on Corporate Returns and Retentions," Review of Economics and Statistics, 57, 400409.

Gruson, Michael \& Wienand Meilicke (1977), “The New Co-Determination Law in Germany," Business Lawyer, 32, 571-590.

Gullickson, William (1995), "Measurement of Productivity Growth in US Manufacturing," Monthly Labor Review, 118 (7), 13-28.

Hart, Oliver D. (1995), Firms, Contracts, and Financial Structure, Oxford, Clarendon Press, New York, Oxford University Press.

Hayek, Freidrich (1945), "The Use of Knowledge in Society," American Economic Review, 35, 519-530.

Hellmann, Thomas \& Enrico Perotti (2006), "The Circulation of Ideas in Firms and Markets," Available at

http://www.lse.ac.uk/collections/RICAFE/pdf/RICAFE2-WP30-

$\underline{\text { Hellmann.pdf }}$

Holmstrom, Bengt \& Steven N. Kaplan (2001), "Corporate Governance and Merger Activity in the United States: Making Sense of the 1980s and 1990s," Journal of Economic Perspectives, 15 (2), 121-144.

Huson, Mark R., et al. (2001), "Internal Monitoring Mechanisms and CEO Turnover: A Long-Term Perspective," Journal of Finance, 56, 2265-2297.

Jensen, Michael (1998), The Takeover Controversy: Analysis and Evidence, The Revolution in Corporate Finance, Joel M. Stern \& Donald H. Chew Jr. eds., Malden Mass, Blackwell Publishers.

Kaplan, Steven N. \& Bernadette A. Minton (2006), "How Has CEO Turnover Changed? Increasingly Performance Sensitive Boards and Increasingly Uneasy CEOs," NBER Working Paper, http://papers.ssrn.com/sol3/papers.cfm?abstract $\mathrm{id}=924751$.

Klein, Benjamin, et al. (1978), "Vertical Integration, Appropriable Rents, and the Competitive Contracting Process," Journal of Law and Economics, 21, 297-362. 
Klein, Burton S. (1977), Dynamic Economics, Cambridge, Mass., Harvard University Press.

Knight, Frank, (1921), Risk, Uncertainty, and Profit, Boston, New York, Houghton Mifflin Company.

Kortum, Samuel \& Josh Lerner (2000), "Assessing the Contribution of Venture Capital to Innovation," Rand Journal of Economics, 31, 674-692.

Kraakman, Reinier (1988), "Taking Discounts Seriously: The Implications of "Discounted" Share Prices as an Acquisition Motive," Columbia Law Review, 88, 891-941.

Kraakman, Reinier, et al., ed., (2009), The Anatomy of Corporate Law: A Comparative and Functional Approach, Oxford, New York, University Press.

La Porta, Rafael, Florencio Lopez-De-Silanes \& Andrei Shleifer (2006), "What Works In Securities Laws?” Journal of Finance, 61, 1-32.

Lerner, Josh (2008), Panacea or Mirage? Venture Capital and Innovation http://www2.law.columbia.edu/contracteconomics/conferences/buslawinn ovation08.htm.

Levine, Ross (1977), "Financial Development and Economic Growth: Views and Agenda," Journal of Economic Literature, 35, 688.

Mack, Ruth (1971), Planning on Uncertainty, New York, Wiley-Interscience.

March, James \& Herbert Simon (1958), Organizations, Cambridge, Mass., Blackwell Publishers.

McDonald, S. (1995), "Learning to Change: An Information Perspective on Learning in the Organization," Organization Science, 6, 557.

Marris, Robin (1971), "The Corporation and Economic Theory," R. Marris and A. Wood, eds., in The Corporate Economy, Cambridge, Mass., Harvard University Press. 
Fox: Promoting Innovation: The Law of Publicly Traded Corporations

Meyer, John Robert and Edwin Kuh (1957), The Investment Decision, Cambridge, Mass., Harvard University Press.

Milhaupt, Curtis J. (2005), "In the Shadow of Delaware: The Rise of Hostile Takeovers in Japan," Columbia Law Review, 105, 2171-2216.

_ (2003), "A Lost Decade for Japanese Corporate Governance Reform: What's Changed, What Hasn't, and Why," Columbia Law School Center for Law and Economic Studies Working Paper.

_ (1997), "The Market for Innovation in the United States and Japan: Venture Capital and the Comparative Corporate Governance Debate," Northwestern University Law Review, 91, 865-898.

Milhaupt, Curtis J. \& Mark D. West (2001), "Institutional Change and M\&A in Japan: Diversity Through Deals," Milhaupt, Curtis J. ed., in Global Markets, Domestic Institutions: Corporate Law and Governance in a New Era of Cross-Border Deals Ann Arbor, Michigan, University of Michigan.

Mitchel, Mark L. \& J. Harold Mulherin (1996), "The Impact of Industry Shocks on Takeover and Restructuring Activity," Journal of Financial Economics, 41, 193-229.

Monsen, R. Joseph and Anthony Downs (1965), “A Theory of Large Managerial Firms," Journal of Political Economy, 73, 221-236.

Morck, Randall, et al. (2000), “The Information Content of Stock Markets: Why do Emerging Markets have Synchronous Stock Price Movements?," Journal of Financial Economics, 58, 215-260.

Mueller, Dennis C. \& S. Lawrence Yun (1998), "Rates of Return Over the Firm's Lifecycle," Journal of Industrial and Corporate Change, 7, 347-368.

Murphy, Kevin J. (2002), "Explaining Executive Compensation: Managerial Power Versus the Perceived Cost of Stock Options," University of Chicago Law Review, 69, 847-870.

Murphy, Kevin J. (1985), "Corporate Performance and Managerial Remuneration: An Empirical Analysis," Journal of Accounting and Economics, 7, 11-42. 
Myers, Stewart C. \& Nicholas S. Majluf. (1984), "Corporate Financing and Investment Decisions When Firms Have Information that Investors do not Have," Journal of Financial Economics, 13, 187-221.

Nelson, Richard R. \& Sidney Winter (1982), An Evolutionary Theory of Economic Change, Cambridge, Mass., Belknap Press of Harvard University Press.

OECD (2005), Science Technology and Industry Scoreboard, Paris, Organization for Economic Co-operation and Development.

_ (2003), Venture Capital: Trends and Policy Recommendations, Paris, Organization for Economic Co-operation and Development.

Rajan, Raghuram G. and Luis Zingales (1998), "Financial Dependence and Growth," American Economics Review, 88, 559-86.

Roberts, Edward B. (1968), "Entrepreneurship and Technology: A Basic Study of Innovators," Research Management, 11 (4), 249-266.

Roe, Mark J., (2002), “Corporate Law's Limits,” Journal of Legal Studies, 31, $233-272$.

Rubenstein, A. (1962) "Organization and Research and Development DecisionMaking Within the Decentralized Firm," Richard R. Nelson, ed., in The Rate and Direction of Inventive Activity, Princeton, Princeton University Press.

Schumpeter, Joseph Alois (1934), The Theory of Economic Development, Cambridge, Mass., Harvard University Press.

Schwert, G. William (2000), "Hostility in Takeovers: In the Eyes of the Beholder?," Journal of Finance, 60, 2599, 2611.

Smith, D. Gordon (1998), "Venture Capital Contracting in the Information Age," J. Small \& Emerging Bus. L. 2, 133-176.

Solow, Robert M. (1957), "Technical Change and the Aggregate Production Function," Review of Economics and Statistics, 39, 312-320. 
Fox: Promoting Innovation: The Law of Publicly Traded Corporations

Strassmann, W. (1964), "The Risks of Innovation in Twentieth Century Manufacturing Methods," Technology and Culture, 5, 215-223.

Stiglitz, Joseph E. \& Andrew Weiss (1981), "Credit Rationing with Imperfect Information," American Economic Review, 71, 393-410.

Tushman, M.L and P. Anderson (1986), "Technological Discontinuties and Organizational Environments," Administrative Science Quarterly, 31, 439465.

Utset, Manuel A. (2002), "Reciprocal Fairness, Strategic Behavior \& Venture Survival: A Theory of Venture Capital-Financed Firms," Wisconsin Law Review, 2002, 45-168.

Ueda, Masako (2004), "Banks versus Venture Capital: Project Evaluation, Screening, and Expropriation," Journal of Finance, 59, 601-621.

Vagts, Detlev F. (1966), "Reforming the "Modern" Corporation: Perspectives from the German," Harvard Law Review, 80, 23-89.

Williamson, Oliver (1985), The Economic Institutions of Capitalism, New York, Free Press; London, Collier Macmillan.

_ (1975), Markets and Hierarchies, New York, Free Press, London, Collier MacMillan.

Winton, Winton \& Vijay Yerramilli, Entrepreneurial Finance: Banks vsersus Venture Capital. http://ssrn.com/abstract $=994630$

World Bank World Development Indications, http://www.google.com/publicdata?ds=wbwdi\&met=ny gdp mktp cd\&idim=country:JPN\&dl=en\&hl=en\&q=japan $+\mathrm{gdp}+$ statistics, http://data.worldbank.org/data-catalog/world-developmentindicators?cid $=\mathrm{GPD}$ WDI. 